\title{
A Review of the Integrated Effects of Changing Climate, Land Use, and Dams on Mekong River Hydrology
}

\author{
Yadu Pokhrel ${ }^{1, *(1)}$, Mateo Burbano ${ }^{1}$, Jacob Roush ${ }^{2}$, Hyunwoo Kang ${ }^{3}$, \\ Venkataramana Sridhar ${ }^{3}$ (D) and David W. Hyndman ${ }^{2}$ (D) \\ 1 Department of Civil and Environmental Engineering, Michigan State University, East Lansing, MI 48824, \\ USA; burbanom@egr.msu.edu \\ 2 Department of Earth and Environmental Sciences, Michigan State University, East Lansing, MI 48824, USA; \\ roushjac@msu.edu (J.R.); hyndman@msu.edu (D.W.H.) \\ 3 Department of Biological Systems Engineering, Virginia Polytechnic Institute and State University, \\ Blacksburg, VA 24061, USA; hwkang@vt.edu (H.K.); vsri@vt.edu (V.S.) \\ * Correspondence: ypokhrel@egr.msu.edu
}

Received: 31 December 2017; Accepted: 1 March 2018; Published: 3 March 2018

\begin{abstract}
The ongoing and proposed construction of large-scale hydropower dams in the Mekong river basin is a subject of intense debate and growing international concern due to the unprecedented and potentially irreversible impacts these dams are likely to have on the hydrological, agricultural, and ecological systems across the basin. Studies have shown that some of the dams built in the tributaries and the main stem of the upper Mekong have already caused basin-wide impacts by altering the magnitude and seasonality of flows, blocking sediment transport, affecting fisheries and livelihoods of downstream inhabitants, and changing the flood pulse to the Tonle Sap Lake. There are hundreds of additional dams planned for the near future that would result in further changes, potentially causing permanent damage to the highly productive agricultural systems and fisheries, as well as the riverine and floodplain ecosystems. Several studies have examined the potential impacts of existing and planned dams but the integrated effects of the dams when combined with the adverse hydrologic consequences of climate change remain largely unknown. Here, we provide a detailed review of the existing literature on the changes in climate, land use, and dam construction and the resulting impacts on hydrological, agricultural, and ecological systems across the Mekong. The review provides a basis to better understand the effects of climate change and accelerating human water management activities on the coupled hydrological-agricultural-ecological systems, and identifies existing challenges to study the region's Water, Energy, and Food (WEF) nexus with emphasis on the influence of future dams and projected climate change. In the last section, we synthesize the results and highlight the urgent need to develop integrated models to holistically study the coupled natural-human systems across the basin that account for the impacts of climate change and water infrastructure development. This review provides a framework for future research in the Mekong, including studies that integrate hydrological, agricultural, and ecological modeling systems.
\end{abstract}

Keywords: Mekong river basin; dams; hydropower; hydrology; climate change

\section{Background}

The Mekong River that is shared by six nations in Southeast Asia is one of the most complex river systems in the world (Figure 1). It originates in the Tibetan Plateau in China and flows through Myanmar, Lao People's Democratic Republic (Lao PDR), Thailand, and Cambodia draining a $\sim 795,000 \mathrm{~km}^{2}$ watershed to the ocean at the Mekong Delta in Vietnam with an annual mean flow of 
$\sim 15,000 \mathrm{~km}^{3} /$ year [1]. It is the 10th largest river in the world in terms of mean annual flow at its mouth, is home to the most productive inland fishery [2], and is the second richest in aquatic biodiversity and freshwater capture fishery after the Amazon [3,4]. The Mekong River Basin (MRB) is characterized by unique and complex hydrologic, climatic, and physiographic features. From its headwaters in the high mountains ( $4500 \mathrm{~m}$ elevation), the Mekong runs through deep, narrow gorges and steep terrains over a $\sim 2200 \mathrm{~km}$ course before it enters the lower basin (the Lower Mekong River Basin-LMRB) at the Golden Triangle where the borders of Thailand, Lao PDR, China, and Myanmar come together (Figure 1). Further downstream, it flows through $\sim 2600 \mathrm{~km}$ of channels before entering the South China Sea in the Mekong Delta [1,3]. These steep mountains in the upper Mekong and flat-fertile lands in its lower portion stretch over vast distances under strong climatic gradients, where natural and managed ecosystems co-evolve under rapid human development, and where many global issues (e.g., river regulation, land cover change, habitat loss, saltwater intrusion, degradation of groundwater quality) are rapidly emerging.

Despite the vast potential for large-scale hydropower development and water diversion for agricultural use, the Mekong has remained relatively unaltered compared to other large river basins in the world $[5,6]$. While several dams have been built over the past few decades, most are in the tributaries or capture only a small portion of the annual river flow [4,5]. The hydrology of the Mekong is thus still largely governed by the natural flow variations with distinct wet and dry seasons (Figure 2) dictated by the seasonal variability of precipitation that supports the highly productive agricultural and riverine ecological systems. The unique combination of these climatic, hydrologic, and topographic features has been the basis for a healthy and resilient natural ecosystem that supports the livelihoods of millions across the region. Food production in the basin relies on timely rainfall and a seasonal flood pulse, and fisheries in rivers, lakes, and wetlands benefit from abundant freshwater and nutrients supplied by the seasonal flood surges, while crops are grown on soils naturally fertilized by nutrient-rich sediments and flows timed with plentiful seasonal rainfall [7]. However, this is changing due to widespread alterations in land use along with the construction of several large dams in the Mekong main stem and hundreds of others in the tributaries. There are also plans to build an additional 16 mainstream and 110 tributary dams by 2030 [2,4,5,8-10]. Figure 1 shows these dams along with the main land use categories [11].

Climate change is expected to add further stress to the region's ecosystems in the decades to come. The wet season flow in the Mekong relies on the Asian monsoon, the rhythm, and intensity of which have noticeably changed in recent years. This has resulted in more frequent floods and droughts, devastating crops, and dramatically altering aquatic ecosystems, which have deeply disrupted rural livelihoods [7,12,13]. Meanwhile, temperature rises in the headwaters of the Mekong River $[8,14]$ are altering the seasonality of stream flows, which has affected agricultural productivity and aquatic ecosystems. There are additional downstream pressures on water quantity and quality across the Mekong Delta due to sea level rise, salt water intrusion, groundwater overexploitation, and aquifer contamination. The combined impacts of the proliferation in dam construction, climate change, and sea level rise will likely result in unprecedented changes in the hydrologic, agricultural, and aquatic systems, especially in the LMRB $[3,8,15,16]$. Studies suggest that maintaining regional food security due to new dam construction and associated fishery loss [17] would require 19 to $63 \%$ expansion of agricultural land [18]. Such agricultural expansion will substantially increase water needs, yet the amount and source of the additional water supplies (e.g., groundwater) and the potential consequences are unknown. Moreover, the MRB hosts some of the world's most productive agricultural systems, especially for cultivation of rice-the world's most consumed grain after wheat [19]. Changes in food productivity in this region will thus have important implications for regional, national, and even global food security [20]. These issues call for a comprehensive analysis of the combined effects of climate change, sea level rise, dam construction, land use change, agricultural expansion, and increased water use on the hydrological, agricultural, and aquatic systems, along with the interactions and feedbacks among these intricately intertwined natural-human systems that are rapidly co-evolving. 
In the Mekong basin, where water, energy, and food (WEF) systems are very closely linked [21], such an analysis should account for all drivers of changes in WEF systems rather than being water-centric as in most previous studies [22].

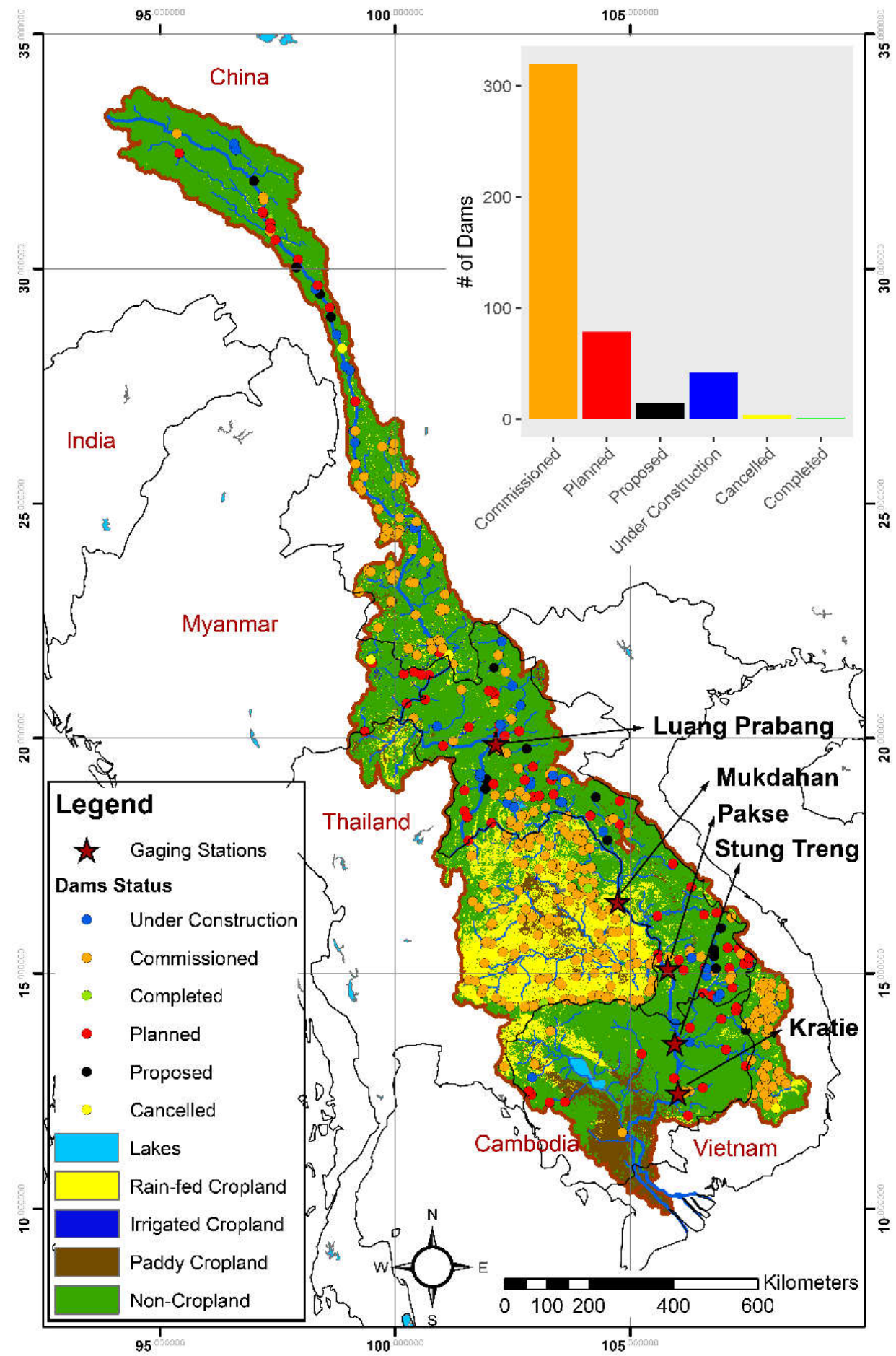

Figure 1. Dams in the Mekong river basin. The background shows land use types and irrigated croplands obtained from Salmon et al. [11]. The inset shows the number of dams under different categories with identical color coding as for the circles in the map. The location of river gauging stations for which river discharge is shown in Figure 2 are displayed as red stars. The dam database was provided by the Research Program on Water, Land, and Ecosystems (WLE), Greater Mekong. 
Here, we provide a detailed review of the existing literature on the hydrology, climate change, land-water management, and human water use in the MRB. The objectives of the review are to: (1) contribute to the ongoing debate on the changing hydrologic regime of the Mekong due to climate change and accelerating human water management activities; (2) highlight key findings from the existing literature; and (3) identify challenges to study the coupled natural-human systems of the Mekong in the face of projected global changes. We present the review in the broader perspective of the emerging issue of WEF nexus, emphasizing the changes in the hydrologic and agricultural systems due to the ongoing dam construction and projected climate change. The remainder of the paper is organized as follows. First, we provide an overview of the historical hydroclimatic variabilities and trend based on observational and modeling studies. Then, we discuss dam construction, changes in land use, and expansion of agricultural and irrigated areas along with their impacts on the water cycle. Next, we provide a brief discussion on the use of groundwater in the Mekong Delta and the potential future changes. Then, we review the existing hydrological models that have been applied over the MRB to examine the impacts of changing climate and dam construction. We also discuss floodplain inundation, flow dynamics, sediment transport, and the changing hydrology of Tonle Sap Lake system along with the effects of climate change and future dams. Finally, we provide a synthesis and future outlook.
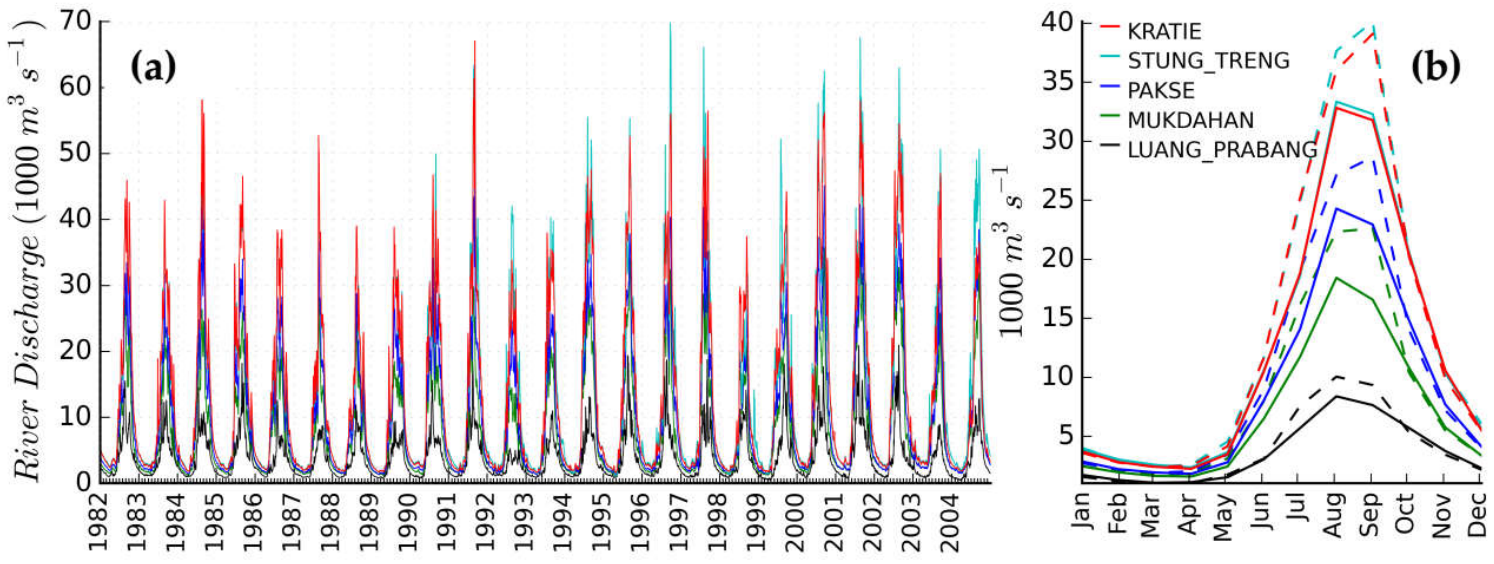

Figure 2. Observed daily river discharge (a) for five gauging stations in the main stem of the Mekong which are shown in Figure 1, and the monthly seasonal cycle (b) for 1982-1992 (solid lines) and 1993-2004 periods (dashed lines). Data source: the Mekong River Commission (MRC).

\section{Historical Hydroclimatic Variabilities and Trend}

Hydrologically, the Mekong River has faced two major issues. First, rapid economic development and growing food and energy needs in its riparian countries have led to plans for massive hydropower development and agricultural expansion, causing deforestation and massive expansion of road networks throughout the region (details in Sections 4 and 6). Second, the highly complex hydrological systems of the Mekong have been affected by climate change. Projections based on climate model results suggest a significant increase in basin-wide temperatures and changes in monsoon patterns. Since the average precipitation and evapotranspiration (ET) over the basin are both expected to increase, it is unclear of how climate change will alter river flows, especially with the overlapping effects of new dams [8]. Predicting how the Mekong will respond to these changes requires a clear understanding of how the system has evolved under the dual influence of climate change and growing human impacts on the water cycle. It is also crucial to understand the interactions and feedbacks among the tightly coupled natural-human systems across the basin. In particular, since the Mekong is only recently starting to stray from its natural flow regime [1,23], it is important to understand the potential changes of the system while management practices are still able to mitigate negative consequences. 
Streamflow in the main stem of the Mekong is characterized by a strong seasonal cycle (Figure 2). Therefore, the differences in seasonal dynamics between the dry and monsoon seasons in the basin play an important role in the system response to human impacts from hydropower and climate change. Comparison of the monthly seasonal cycle during 1982-1992 and 1993-2004 periods suggests that the amplitude of the flood pulse has generally increased (Figure 2) at all five stations (Figure 1) in the middle and lower reach of the basin. However, a recent study that used the more recent flow records from the Chiang Saen station in the Upper Mekong suggests a decrease in maximum flows accompanied by an increased rate of flow decrease following the completion of upstream dams [24]. Upstream dam completion likely increases dry season flows and water level fluctuations, and the dam-induced fluctuations in upstream flows increase the variability in downstream flows more in the dry season than in the wet season. Studies suggest that flood duration, amplitude, and maximum water level decreased throughout the basin due to dam construction [24], which has also caused a significant delay in the start, peak, and end of seasonal flood pulse [25].

In the Upper Mekong precipitation was found to have increased dramatically from 1950s to 2010s at both the seasonal and annual scales, and especially in spring [26]. However, this is contrary to other studies on the Lower Mekong, which suggest that precipitation has not significantly changed over the past 50 years $[27,28]$. There have been widespread and significant increases in Upper Mekong temperatures, with a recent acceleration in rate. The most significant temperature changes are felt in winter months. Water levels measured at upstream dams show similar patterns before and during dam construction, suggesting that climatic factors have a significant influence on Upper Mekong water-level variations [29].

Analyses of flooding trends over time have shown a decrease in the average magnitude of Lower Mekong floods but the variability in flood magnitude has increased. The likelihood of extreme floods or low flows has increased through time, even before the construction of the first dams [30], which suggests that the shift in flood variability is likely due to large-scale atmospheric mechanisms. Studies have shown that climate variability and change in the Mekong region is primarily governed by the El Niño-Southern Oscillation (ENSO), which modulates the variations in the Asian monsoon, including the Western North Pacific Monsoon (WNPM) and Indian Summer Monsoon (ISM) [31,32]. It has been suggested that the long-term changes in river flows and floods in the southern part of the basin are closely linked with the variability in WNPM [33]. Additionally, the relationship between ENSO, the WNPM, and ISM are transient on a decadal scale and have been shown to vary in magnitude since the 1970s [32,33]. Since there is a close connection between Pacific sea surface temperatures and monsoon variability, an increase in sea surface temperatures due to climate change is expected to be accompanied by increased variance of monsoon patterns and associated floods [33].

Differences in flood variability exist between the upper and Lower Mekong because the hydrology of the two regions is controlled by different atmospheric processes; the upper basin flows are controlled more by snowmelt and precipitation, while the lower basin flows are mostly linked to intense rainfall during the monsoon season [30]. The strength of the ISM has a strong inverse relationship with precipitation in the Northern basin. Furthermore, the Pacific decadal oscillation influences the variability of the WNPM [33]. There are no mechanisms that clearly explain relationships between these climatic systems, but it has been suggested to be a consequence of natural climate oscillations, anthropogenic climate change, and changes in land or water use [30]. Further research that includes a more mechanistic approach to understanding atmospheric dynamics should help project how these systems will respond to changes in land use and climate.

Following the construction of the first major Mekong dams, climate change has been linked to $\sim 82 \%$ of the flow change from 1991 to 2009 . However, for the $2010-2014$ period, $\sim 62 \%$ of the observed changes in flow [24] were found to be related to hydropower development. This disparity highlights the accelerating influence of direct human activities on the hydrology of the Mekong. The relative hydrologic impact of hydropower is expected to increase as more hydropower projects are completed. 


\section{Dams in the Mekong and Their Hydro-Agro-Ecological Impacts}

The strong topographic gradient, rugged terrain, and high flow volumes provide ideal conditions for large-scale hydropower development in the Mekong. The hydropower potential of the mainstem Mekong has been estimated to be $\sim 53,000$ MW with another 35,000 MW from tributaries $[9,34]$. Of this enormous potential, only a small fraction has been utilized thus far. Therefore, the developed hydropower capacity of existing project in the Mekong is currently very small relative to the installed capacity in the other two large rivers on the western Pacific: the Yellow and the Yangtze [27]. In particular, a huge amount of hydropower generation potential in the LMRB remains largely untapped. Laos alone has the theoretical potential of $\sim 26,000 \mathrm{MW}(\sim 18,000 \mathrm{MW}$ is technically feasible) [35,36]; of this only a tiny fraction was developed by the early 2000s [37] but the installed capacity increased to $\sim 4200 \mathrm{MW}$ in 2015 [35].

In the Upper Mekong, which is called the Lancang River, China has been developing hydropower projects as a cascade of dozens of mega dams (Figure 1); more than six of those have been completed in recent years and more than twelve others are under construction or planned for the near-term future [38]. These existing upper Mekong dams have already caused large-scale and trans-boundary impacts throughout the basin and the Lower Mekong dams are expected to largely compound these impacts by causing abrupt changes in water levels, altering sediment transport, and blocking fish migration [17]. Since there is still great untapped potential in the Lower Mekong, downstream countries have also been accelerating dam construction. While some large dam projects have recently been completed, others are under construction, and hundreds of others are planned [17] (Figure 1). Among those planned are 16 dams in the main stem (11 in the LMRB) and over 100 in the tributaries, most of which are expected to be completed by 2030 [2,4,5,8-10]; of the 11 planned in the LMRB, the Xayaburi is the first that is expected to go into operation in 2020. While Xayaburi dam has been built to fulfill the growing regional energy needs (its installed capacity will be 1,285 MW), experts believe that the energy supply will come with unprecedented and devastating costs to the environment and livelihoods of tens of millions of people in the region $[9,17,39]$. The dam will likely cause irreversible and permanent ecological change to the Mekong by altering the natural flow regime and adversely affecting fisheries and other aquatic resources; it will also affect flood-recession ecosystems in the lowlands and impede sediment delivery to the Mekong delta region [39-43]. Growing transportation networks, especially the mountain roads in headwater catchments, some of which are linked with the construction of new dams are causing significant changes in sediment production and deposition in river channels [44]. The dam will likely cause basin-wide changes, but the impacts are expected to be felt the most in the regions surrounding and downstream of the dams where serious threats to food security through loss of fisheries and agriculture are likely [2].

The Don Sahong (260 MW) and Pak Beng (912 MW) are the second and third largest dams, respectively, among the 11 mainstream cascade dams planned in the LMRB. Construction of these two dams has been approved despite significant controversies due to the complaints about their environmental impacts and long-term implications for ecological well-being and regional food security [17]. Similar to the Xayaburi dam, these two dams could irreversibly alter fish migration throughout the LMRB, with potentially devastating consequences for the river's richest ecosystems and the livelihoods of hundreds of thousands of people [45].

Several other hydropower projects are being planned in the tributaries of the Lower Mekong, including many in the Sekong, Sesan, and Sre Pok River basins that constitute the largest sub-watershed of the Mekong and are collectively known as the $3 S$ river system. The combined runoff from the $3 \mathrm{~S}$ rivers contributes $\sim 17 \%$ of Mekong's annual discharge with an estimated hydropower capacity of $9500 \mathrm{MW}$ [27]. One of the first dams constructed in the Sesan river was the Yali Falls dam (900 MW capacity), which caused significant downstream flooding during initial operation, with major effects to fisheries and the livelihoods of villagers in Cambodia and Vietnam that were dependent on these fisheries (www.internationalrivers.org/campaigns/sesan-dams; accessed on 21 December 2017). The dam has been criticized for its adverse effects with increasing concerns associated with 
downstream water quality, fisheries, irregular water level fluctuations, many of which remain poorly characterized [27]. A recent study examined the potential impacts of the planned dams in the Lower Mekong tributaries and suggested that the Lower Se San 2, Se Kong 3d, Se Kong 3u, and Se Kong 4 dams would cause a basin-wide fish biomass drop by $9.3 \%, 2.3 \%, 0.9 \%$, and $0.75 \%$, respectively [2]. A large number of additional dams are planned in the $3 S$ basin in the next few decades (Figure 1) [27].

The flow alterations by future dams will affect a wide range of hydrological, agricultural, and ecological systems across the basin, potentially threatening regional food security while fulfilling future energy needs. The growing regional and global concerns about these adverse impacts of large-scale dam construction and climate change have led to increasing interests in studying the WEF systems in the Mekong basin. Studies have modeled scenarios of future development to explore the likely hydrologic impacts of dam construction $[2,4,8,25,46]$ and climate change $[16,23,47,48]$, as well as the changes in downstream sediment delivery $[40,41,43,49]$ and coastal groundwater $[50,51]$. While the consequences of some of the large dams have been thoroughly assessed [34], the cumulative and broader effects of all dams on the WEF systems across the basin, especially when combined with the effects of changing downstream hydrologic processes (e.g., flooding and recession, groundwater recharge from floodplains, coastal groundwater dynamics) remain largely unexamined [2,9].

Some studies suggest that the construction of the planned dams alone would result in catastrophic effects on agriculture, fisheries, and biodiversity [2,52]. For example, research shows that the completion of 78 dams on tributaries would greatly reduce fish productivity and biodiversity [2], but a thorough assessment of the transboundary cumulative impacts of the tributary dams have not yet been conducted. Therefore, there is an urgent need for a comprehensive, basin-wide analysis of the integrated effects of dam construction and climate change on streamflow, sediment transport, fisheries, and downstream communities. Such assessments should consider additional factors including the changes in land use caused by dam construction, the potential expansion of mountain roads associated with new dams and their impacts on sediment production and transport [44,53-55], and the positive hydrological, agricultural, and ecological benefits that dams may bring.

In general, large reservoirs hold water during wet season and release it during the dry season, essentially increasing the dry season flow [56], but the impacts are beyond the changes in flow seasonality and magnitude. Water impoundment behind dams can alter the dynamics of terrestrial water storage (TWS) [57], which can affect groundwater systems and offset sea level rise [58]. The Xiaowan and Nuozhadu dams in the Upper Mekong (the Lancang River), constructed in 2010 and 2014 respectively, significantly increased dry-season flows and decreased wet-season flows [24]. The increase in dry-season flow can benefit downstream agricultural irrigation, while the reduction in wet-season flows can be beneficial for downstream flood and drought management and navigation, and supports important instream ecosystems [24]. Higher dry-season flows can also help maintain groundwater levels, which can reduce the energy costs for irrigation.

Flow regulation by dams in the Upper Mekong has also been found to potentially reduce the increase in magnitude and frequency of flood due to climate change consistently throughout the 21st century [59]. Findings from global studies also suggest that water scarcity areas tends to travel downstream in regions where flows are significantly regulated by dams [60]. A recent study has proposed ways to design reservoir management in the Mekong by carefully analyzing the characteristics of the flood pulses, which could help increase fishery yield and improve the food system efficiency in the Lower Mekong [61].

\section{Land Use Change and Agricultural and Irrigation Expansion}

Historically, the primary changes in land use in the MRB have been dominated by the conversion of forested areas into cultivated lands [62-64] (Figure 3). It is evident from Figure 3 that there has been an increase in conversion of large forests areas into agricultural and urban lands over the past few decades, which is primarily due to rapid population growth, urbanization, and socio-economic development in the countries within the MRB [65]. It should be noted that the land use categories in 
Figure 3 do not explicitly include the rapidly changing road networks in rural areas of the region [44]; roads are often categorized as bare soils, urban areas, or agricultural lands. Today, agriculture provides livelihoods for $75 \%$ of the residents of the LMRB. The regional population grew by nearly $45 \%$ between 1980 and 2000 and is projected to increase further over the next 20 years, placing additional pressure on the land and water for additional food production [16]. In the LMRB where the mosaic of natural vegetation, seasonally inundated areas, wetlands, and cultivated lands shape the landscape, changes in seasonal flow patterns and flood pulses due to climatic changes and dam construction have been suggested to strongly influence land use patterns [66]. Studies have found that water infrastructure development and associated agricultural and irrigation expansion could have profound influence on open water areas and rainfed habitat, especially in the seasonally inundated areas around the Tonle Sap Lake $[47,67]$.
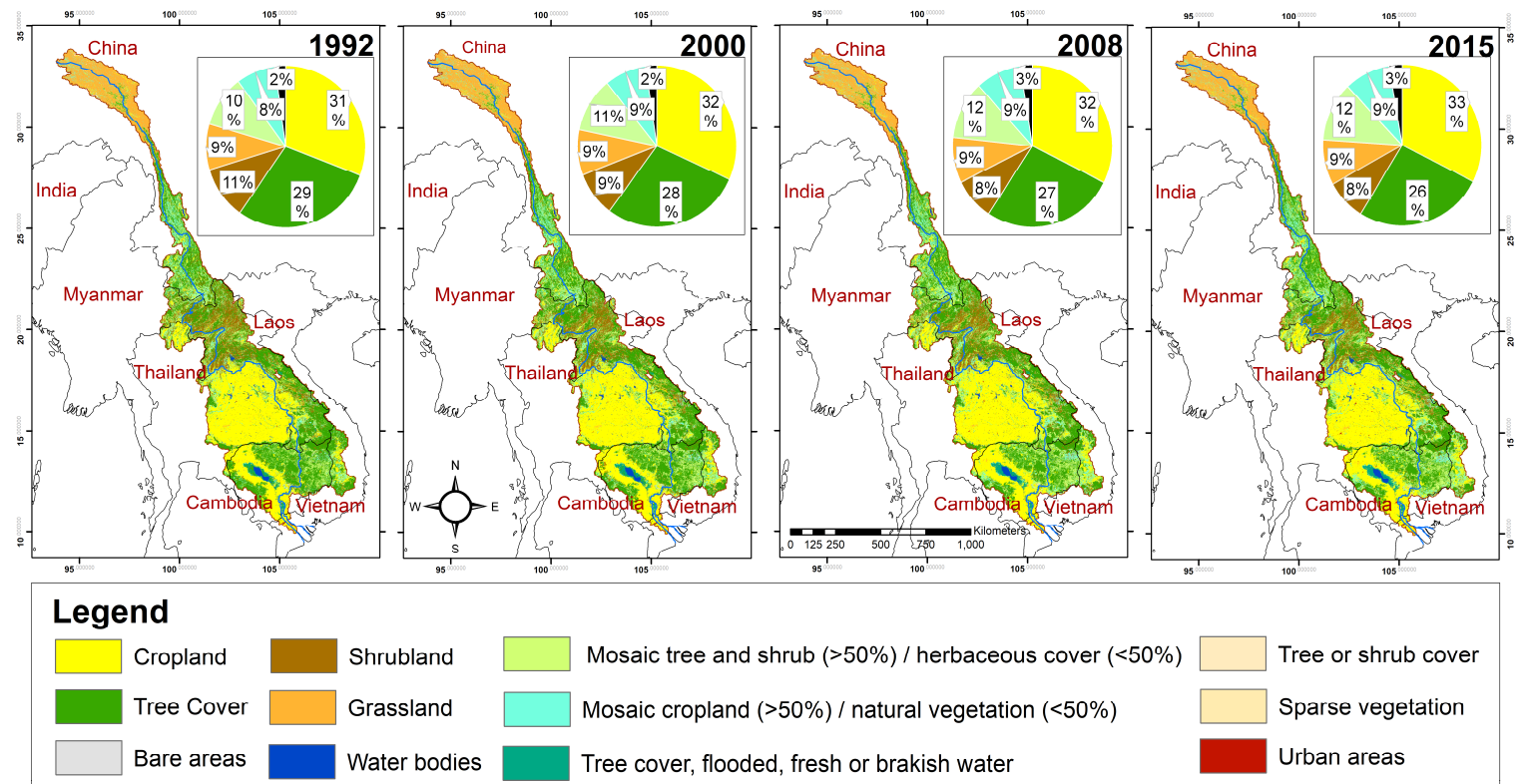

Figure 3. Major land use and land cover types for 1992, 2000, 2008, and 2015. The pie charts show the fraction of each land cover type with identical color coding as in the maps except for the black color that includes all other land cover types than those shown in the charts. Urban areas are not shown in pie charts as they represented only $0.06 \%$ of basin area in 1992 and increase slightly to $0.08,0.15$, and $0.27 \%$ in 2000, 2008, and 2015, respectively. Data source: European Space Agency-Climate Impact Initiative (ESA-CCI: https: / / www.esa-landcover-cci.org/, accessed on 27 January 2018).

Dam construction can also facilitate irrigation expansion with potential changes in cropping patterns, but global irrigation data [68] suggest that the Mekong has not yet seen such widespread irrigation expansion in the past three decades. Caution should however be made that there could be underreporting of irrigated areas in the global database. The irrigation sector of the region is complex and poorly understood. Irrigation development is largely ad hoc and uncoordinated, with very little information available on the details of existing irrigation schemes [69]. Documented reports suggest that irrigation in upland areas is mainly for wet season rice, which is generally gravity driven with reasonably low requirements for management [69]. Survey-based studies also report that most irrigation projects still use traditional weir-type structures, although mechanized irrigation is becoming more common. More than 19,000 irrigation schemes were in use by 2000, of which most were traditional weir-type structures in mountainous northern and central regions and only small number of pumping irrigation schemes were in use in the south [70]. Irrigated wet season rice is the primary crop, especially in the LMRB, and there are limited opportunities for dry season crops due to limited 
water availability. While rain-fed rice dominates farming in Lao PDR, the central highlands of Vietnam, Thailand, and Cambodia, fully or partially irrigated rice is grown throughout the year in the Mekong Delta region. Other crops such as fruits, vegetables, and industrial crops are also rapidly expanding in recent years [70]. Supplemental irrigation is also used for other crops such as soybeans, mung beans, peanuts, and watermelon, which are primarily grown in Lao PDR, Thailand, and Cambodia. In the Mekong delta, there has been a substantial increase in irrigation for fully irrigated rice and fruit trees [69].

Because of the extensive waterlogging and inundation during the wet season, most areas in the rainfed lowlands of Laos, Northeast Thailand, and Cambodia, and in the irrigated Mekong Delta in Vietnam, are more suited to growing rice than other crops. After a rainy period, the water table rises, often above the soil surface causing inundation [16], which is amplified by the slow infiltration rates over the hard plough pan or seal surface formed by predominantly sandy loam soils, resulting in temporary waterlogging after initial rainfall or irrigation. Because upland crops do not grow well in these soils, cropping systems in the LMRB are mostly used to cultivate rice, which is the staple food for most of the population. Resource-poor farmers operate on low cash flows and carefully weigh the risks of adopting more expensive farming practices that generally have high returns but carry a greater risk of failure [16].

Cropland expansion adversely affects land surface properties (e.g., surface roughness and albedo) and hydrologic processes [71]. Thus, changes in land cover type and application of additional water through irrigation can substantially alter both the water and energy balance on the surface [56,72-76]. Global modeling studies have found that while the basin-scale changes in runoff, ET, and land surface temperature due to cropland expansion and irrigation are small, the changes over highly irrigated areas in the LMRB are significant $[56,73]$. Studies at the sub-basin levels have also found significant impacts of land use and land cover change on water balance. For example, Homdee et al. [77] applied the Soil and Water Assessment Tool (SWAT) model in the Chi River basin in Thailand and found that land use change largely affected annual and seasonal water yield and ET. Conversion of forested area and agriculture land affected basin water flows and ET and replacing sugarcane crops with paddy fields clearly reduced water flows and increased ET by almost $5 \%$ during the dry season, which was associated with increased irrigation for rice paddies. The expansion of rice paddy fields also had a significant effect on the seasonality of flows, a decrease in ET by $12.0 \%$, and an increase in water yield by $5.1 \%$ during the dry season.

It is highly likely that there will be a substantial expansion of croplands and irrigated areas to replace food loss due to declines in fisheries [2]. Construction of dams will also likely affect the seasonally inundated floodplains and wetlands around Tonle Sap Lake and the Mekong Delta region $[23,78,79]$. While there is a general and growing consensus that the future dams and associated changes in land use (direct and indirect) will result in basin-wide hydrological and ecological impacts, the scale and magnitude of such impacts have not yet been quantified. These changes in land use will also feedback to the hydrologic system and alter flows and ET. Studies have shown that the potential impacts of future water resource development in the Mekong could reduce wet season flows by $4-14 \%$, reverse flow to the Tonle Sap Lake by $7-16 \%$, increase flooded areas by $5-8 \%$ and cause salinity intrusion areas in the Vietnam Delta by $15-17 \%$ [80]. The potential impacts of changes in climate, land use and land cover, and population on future water availability and demand in the Srepok River basin (one of the $3 S$ river systems in the Lower Mekong) was evaluated by Ty et al. [81,82]. They revealed that while surface runoff may increase due to increased precipitation, changes in land use will increase water demand, exacerbating water stress conditions both at the basin and sub-basin scales, especially during the dry season. Future studies should attempt to improve the understanding of the integrated effects of climate change and alteration of land uses due to dam construction and other related water management activities over the entire river basin. Such studies should employ the latest generation of models that bring together the hydrological, agricultural, social, and ecological aspects into a single-consistent framework [83-86]. 


\section{Availability and Use of Surface Water and Groundwater Resources}

The Mekong River's mean annual discharge of $\sim 475 \mathrm{~km}^{3}$ [1] provides relatively high per capita water resources compared to other international river basins. Therefore, the basin-wide and annual surface water withdrawal to availability ratio is small $[3,87]$. However, the high temporal variability in river flow and uneven distribution of agricultural areas within the basin (Figures 2 and 3) creates water scarcity during the dry season (February-May; critical irrigation period for rice cultivation) when the flow becomes less than $10 \%$ of average annual flow and the demands are the highest, especially in the Lower Mekong [16]. Flows are high during the wet season (July-October) when rainfall provides most crop water needs. The strong seasonal variation in water availability is reflected in Figure 2. If low flows decrease further due to climate change, shortages will likely occur, especially in the Mekong Delta, during the dry season when the flows are lowest; however, it is likely that new upstream dams will increase the dry season flows [59]. In the Lower Mekong, more than $41 \%$ of the watershed areas are used for agricultural production (Figure 3), which is steadily increasing to produce more food for the burgeoning regional population [70]. It has been estimated that the annual water utilization for agriculture in the Lower Mekong is less than $4 \%$ of the total annual flow [16]. Basin-wide, agriculture consumes the largest fraction of the water abstractions from the Mekong River, accounting for $80-90 \%$ of all abstractions.

Groundwater is a critical resource in the MRB but studies on groundwater-based irrigation have received less attention than those focusing on surface water systems because there is far less groundwater use for irrigation compared to other agricultural regions in the world $[85,88]$. While some information exists on the size and extent of aquifer systems, thorough investigations have not been conducted, and as such the available information on the groundwater resource size, utilization, sustainability, and quality is rather limited [89]. Groundwater is used as a major source of drinking water supply in Cambodia and Thailand [70,90], and there is an increasing trend toward large-scale exploitation for industrial and agricultural purposes [90]. Groundwater is also used to irrigate coffee plantations in the highlands of eastern Cambodia and mountainous regions of Lao PDR, and rice and other crops in the Mekong Delta in Vietnam [70]. It is estimated that more than one million wells access groundwater for domestic, agricultural, and industrial needs in the Mekong Delta region in Cambodia and Vietnam, which is a major increase from a limited number before the 1960s [91,92]. For irrigation, there has been an increasing use of groundwater during the dry season when surface water becomes less available and accessible due to reduced water levels in rivers [89]. Global groundwater data [93], based on the inventory of the International Groundwater Resources Assessment Center (IGRAC) suggests that groundwater abstractions in the MRB in 2000 were $\sim 550$ Million $\mathrm{m}^{3}$ /year; this is significantly less than the country-based groundwater use reported in other studies (e.g., [90]), likely because the groundwater used across the basin by individual households may not have been reflected in the global database. There are no time-varying groundwater use datasets to examine the historical changes. Under climate change, groundwater demand is expected to increase significantly as surface water will likely becomes less accessible [89]. However these results should be interpreted with caution because flow regulation by future dams will increase in dry season flows [24], which has not been accounted for in these studies.

The region's reliance on groundwater has especially increased in the Lower Mekong where groundwater provides critical services including supplying drinking water for millions, supporting the wetland habitat, and preventing saltwater intrusion in coastal areas [94]. Widespread aquifer storage depletion, water quality deterioration, and saltwater intrusion are already emerging in parts of the delta as a result of the compounded effects of the groundwater overexploitation and sea level rise due to climate change $[20,50,51,91,95]$. The Mekong Delta covers $50,000 \mathrm{~km}^{2}$ of fertile alluvial plain extending from Kratie in central Cambodia to Vietnam's East Sea. The Vietnamese portion of the delta is crucial for rice production and contributes to almost $100 \%$ of its rice exports [94]. The intensified paddy rice agriculture in Vietnam has largely transformed the delta by draining large wetland areas and using increasingly sophisticated water management projects; these manipulations in hydrology 
and flooding patterns have significantly altered groundwater systems by changing recharge and withdrawals [96]. The use of agrochemicals has also caused deterioration of groundwater quality. The declining water tables, deteriorating water quality, and increasing saltwater intrusion are already posing enormous threats to farming systems, wetland ecology, and livelihoods of more than 4.5 million people that rely on groundwater for drinking [94,97]. Groundwater overuse has also been found to exacerbate arsenic contamination in groundwater in regions such as the southern Cambodia [98], and it is likely that climate change will further exacerbate these problems [89].

The lowered water table in the coastal regions from irrigation pumping is exacerbating saltwater intrusion problems $[50,95,99]$. Pervasive pumping of groundwater has also resulted in large-scale land subsidence, which studies have linked to the release of arsenic in deep groundwater of Pliocene-Miocene age [91] through vertical migration. Based on the analysis of such old groundwater aquifers that are widely pumped, they found that intensive groundwater extraction is causing land subsidence of up to $3 \mathrm{~cm}$ /year as shown by satellite-based radar images and 3D groundwater simulations. The groundwater levels are persistently declining in the Vietnamese portion of the Mekong Delta at a rate of $\sim 0.3 \mathrm{~m} /$ year based on data from nested monitoring wells, with an average land subsidence rate of $\sim 1.6 \mathrm{~cm} /$ year [50]. The occurrence of high salinity (salt water intrusion due to sea level rise and groundwater use) and Arsenic content in groundwater could limit agricultural production and pose serious human health risks in the future [51,100-102]. A recent study confirms that excessive groundwater abstraction is the primary driver of land subsidence [95], which has increased dramatically over the past 25 years.

While the existing groundwater issues in the Mekong delta region, have been primarily caused by increasing abstractions and saltwater intrusion, other factors are likely to play increasing roles in the future. One such factor that has not yet resulted in discernable and widespread effects in the downstream groundwater systems is the construction of upstream dams and water diversion for irrigation. Climate change has resulted in basin-wide changes in precipitation and temperatures (details in Section 8); the resulting changes in groundwater recharge patterns as well as the downstream flood pulse are also expected to affect the groundwater systems in the delta region [20]. Upstream dams may also bring some positive effects on groundwater systems. For example, the increased dry-season flows from upstream hydropower dam release could limit salinity intrusion in the Mekong Delta during the dry season, but reduced flows may limit salt flushing during the wet season. These effects when compounded by the changes in the hydrology of the delta due to climate change could be far more complex. A thorough and holistic analysis of the integrated effects of the multitude of factors that affect groundwater systems is thus necessary to provide a clear picture of effects under various scenarios of changing climate, water management, and socio-economic growth.

\section{The Flood Pulse, Tonle Sap Lake System, and Sediment Transport}

Floodplain inundation dynamics and sediment transport are critical components of the hydrological, agricultural, and ecological systems in the MRC [23,47]. The seasonal hydrological regime with a strong unimodal flood pulse pattern [103] is the primary driving force for the Lower Mekong ecosystems [66], providing a timely supply of water and nutrient-rich sediments to support flood-recession agriculture, inland fisheries, and extensive instream and wetland ecosystems. The duration, amplitude, timing, and rapidity of the flood pulse are critical characteristics that determine the stability and productivity of the supported ecosystems [23].

A unique hydrological feature of the Mekong flood pulse is the reversal of flow from Tonle Sap Lake (Figure 4), which receives water from the mainstream Mekong during the wet season then flows to the Mekong during the dry season. The flood pulse from the Mekong inundates the floodplains around the lake to a depth of up to $9 \mathrm{~m}$ over several months [66]. About $54 \%$ of this water originates from the Mekong, with the rest coming from tributaries $(\sim 34 \%)$, and precipitation over the lake $(\sim 12 \%)[23,46,104]$. Tonle Sap Lake, which is home to one of the world's most varied and productive ecosystems, is the largest lake and wetland ecosystem in the Mekong basin. Its floodplain extends over 
$15,000 \mathrm{~km}^{2}$ and stores $50-80 \mathrm{~km}^{3}$ of water (during a typical flood season) from the Mekong that enters the ecosystem during the monsoon season $[1,47]$.

This river-lake system supports the world's largest freshwater fishery, which provides most of the protein consumed in the Cambodia $[1,105,106]$. Tonle Sap Lake also supports critical ecosystems and agriculture in the Mekong delta by providing higher dry season flows than those from the main stem [107]. The bottom of the lake is at an altitude of 0.6-0.7 $\mathrm{m}$ a.s.l during low water, with the water depth of $\sim 0.8 \mathrm{~m}$. Kummu and Sarkkula [23] reported that the daily lake water levels vary from a minimum of $\sim 1.32 \mathrm{~m}$ to the peak flood of $\sim 9.14 \mathrm{~m}$, and the flooded areas vary from $2215 \mathrm{~km}^{2}$ to $13,258 \mathrm{~km}^{2}$, with a corresponding storage volume of $\sim 1.6 \mathrm{~km}^{3}$ and $\sim 59.7 \mathrm{~km}^{3}$, respectively. Storage in the lake is expected to increase, which would cause the maximum and minimum lake areas and water levels to increase every year [89]. The timing of the flood pulse onset will also likely change with high water levels early in the year and longer inundation periods [89]; however, these future projections will likely change significantly if the effects of the proposed dams are considered.

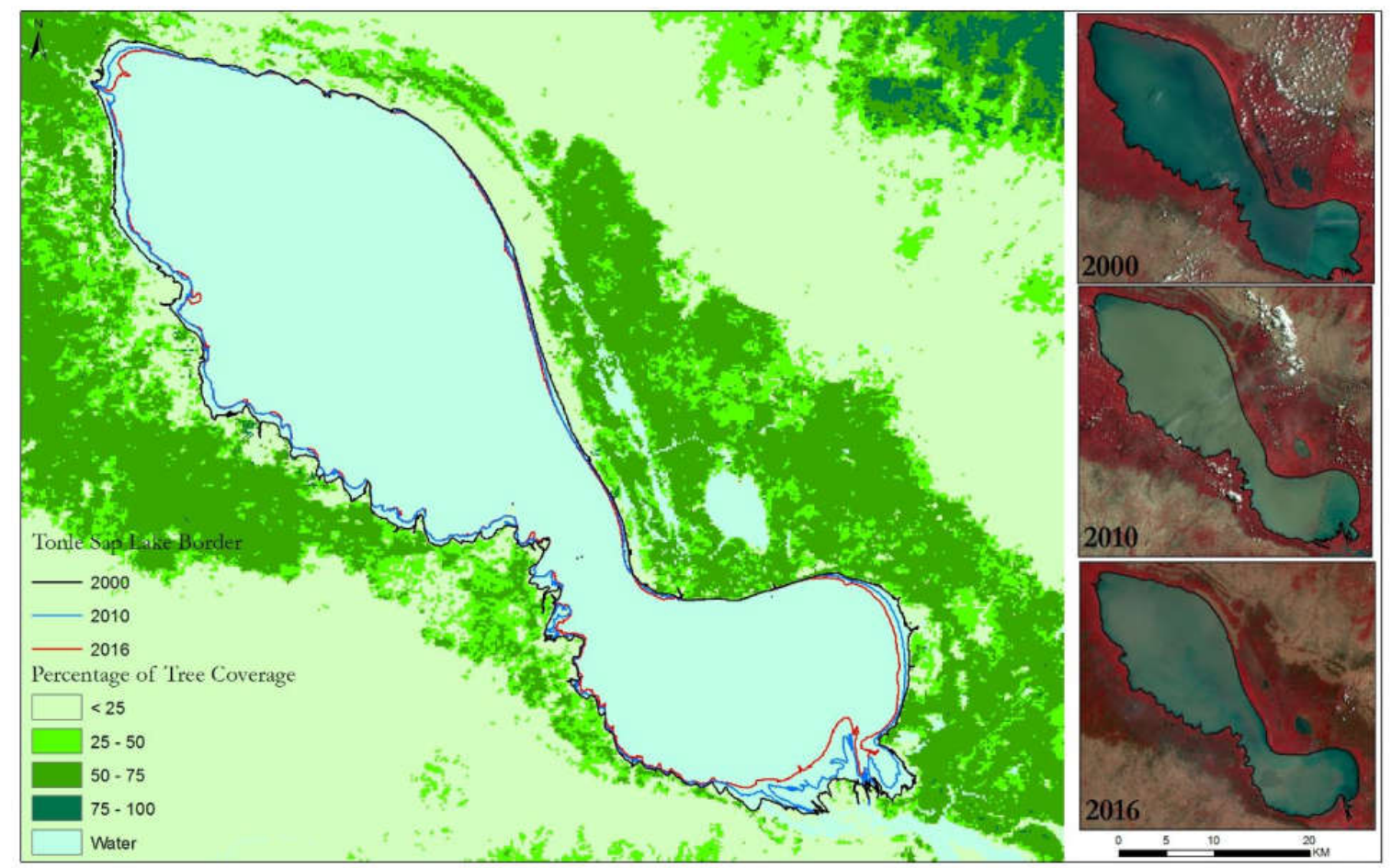

Figure 4. Changes in open water boundaries in the Tonle Sap Lake region extracted from Landsat imagery of 2000, 2010, and 2016 overlaid with Moderate Resolution Imaging Spectroradiometer (MODIS) vegetation continuous field (modified after Lin and Qi [67]).

Historically, the timing of Mekong flood pulse peak has remained stable with some variations in the beginning and end of the flooding season depending on flood timing on the main stem and local rainfall in the Tonle Sap tributaries [23]. However, this historical pattern is changing due to climate change and rapid water infrastructure development and basin management for hydropower generation, irrigation, water supply, and flood control, which makes the future of the Tonle Sap uncertain [47]. Of particular interest is the construction of a series of large hydropower dams both in the main stem Mekong and its tributaries (see Section 2). Even though a comprehensive study of the impacts of dam construction, agricultural expansion, climate change, and sea level rise have not yet been conducted, large-scale modeling studies and observational data suggest that planned hydropower development would dramatically alter the Mekong flow and Tonle Sap lake system $[5,8,27,66]$. Open water areas in the Tonle Sap Lake have been suggested to have declined from year 2000 and 2016 [67] (Figure 4), but studies suggest that water infrastructure development 
could increase the open water areas and rainfed habitats, while reducing the area of seasonally flooded habitats [47]. If the current trends of economic growth continue, irrigated areas in the Mekong could increase by $43 \%$ and $65 \%$ by 2030 and 2060, respectively [13,47,69], which will come with changes in land use patterns and significantly alter the hydrology of the basin (see Section 4). Tonle Sap River discharges a maximum of $10,000 \mathrm{~m}^{3} / \mathrm{s}$ from the lake toward the Mekong Delta from June to October $[47,108]$. There could be a reduction in flood depth during the wet season by over $0.5 \mathrm{~m}$ and an increase in water level during the dry season by $0.2-0.6 \mathrm{~m}$, which could reduce the flooded areas by $400-900 \mathrm{~km}^{2}$. Consequently, flooded areas covered by forests could be reduced by $22-100 \mathrm{~km}^{2}$, grasslands by $50-150 \mathrm{~km}^{2}$, and rice fields by $300-630 \mathrm{~km}^{2}$ [47]. Small rises in the dry-season lake water level would permanently inundate large areas of floodplain, which would disrupt natural vegetation cycles and negatively affect ecosystem productivity.

Reliable sediment data for the Mekong are not available, and the available data are poorly documented [43]. Some estimates have been made [109-112] that suggest an annual sediment flux in the range of 150 to $170 \mathrm{Mt}$ but there is high uncertainty in the estimates due to a lack of referencing to the original data and methodology [43]. In the Mekong, most of the sediment upstream of Cambodia is stored inside the channel and, unlike in other rivers such as the Amazon, there is little sediment exchange between channels and floodplains except in the Cambodian lowlands and Mekong delta $[43,113]$. There are a number of sediment monitoring stations along the mainstem Mekong [42], but there is a lack of basin-wide sediment monitoring network, especially for small tributaries and headwater catchments where a multitude of factors affect sediment generation, deposition, and transport. Studies conducted over different regions in rural Southeast Asia suggest that road networks, especially the mountain trails, which are often associated with agricultural expansion and dam construction, are one of the major drivers of changing sediment dynamics in the region $[44,53-55,114]$. These studies suggest that the rapid increase in road density in mountainous areas has resulted in an increase in surface erosion and landslides causing loss of soil and sediments which can affect agricultural productivity due to topsoil erosion along with severe impacts on water quality, aquatic habitat, flood, and navigation in the downstream [44].

Along the upper catchments of the Mekong River in Yunnan, China, steep slopes below many of the newly created roads led to a mass delivery of landslide sediments directly into the rivers, severely impacting downstream ecosystems [44]. Sidle et al. [53] found that landslide and erosion induced by Weixi-Shangri-La road in Yunnan region delivered 19 times more sediment to the rivers than the remaining $99.6 \%$ of the contributing catchment. The aggressive construction of rural roads in the hilly terrains of Southeast Asia has also likely impacted traditional cultivation methods [115] which are expected to be further altered by the construction of new dams with associated changes in river flow and floodplain dynamics [18]. Such alterations in sediment dynamics have often been attributed to widespread deforestation and agricultural expansion [44].

Construction of the planned dams in the main stem and tributaries of the Mekong, which is expected to increase the storage capacity by $10 \mathrm{fold}$, would increase the sediment trapping efficiency from 15-18\% to 51-69\% [40]. In the Chinese part of the basin-the upper Mekong-existing reservoirs have the potential to trap about $32-41 \mathrm{Mt}$ of sediment annually, and if the planned cascade dams (Figure 1) are built, the sediment trap efficiency would increase to $78-81 \%$ which would trap approximately half of the basin-wide annual sediment load ( 140 Mt) [40,43]. Recent studies that used a combination of a quasi-2D hydrodynamic model and a cohesive sediment transport model, provide a dire picture suggesting that if all planned dams in the Mekong are built, $\sim 96 \%$ of the historical sediment load of the pre-dam period would be trapped [116,117]. In some parts of the basin, the projected rise in temperature of up to $3{ }^{\circ} \mathrm{C}$ and changes in precipitation ranging from $-27 \%$ to $41 \%$ would change sediment yield ranging from a decrease by $17 \%$ to an increase by $66 \%$ annually [49]. Shrestha et al. [49] also found a large inter-annual variability in the changes in sediment yield as well as a large spread among the projections from different climate models. The potential impacts of future 
dams add further complexities to the already large uncertainties in estimates of the magnitude and direction of changes in sediment yield.

Nutrient-rich sediments from the Mekong provide the critical support for the biological productivity and floodplain agriculture in the Lower Mekong and the Tonle Sap area [41,117]. Sediment depositions in the Mekong Delta provide more than 50\% of mineral fertilizers typically applied for rice crops in non-flooded ring dike floodplains in Vietnam [117]. Therefore, a reduction in sediment delivery may threaten the highly productive biological and agricultural systems but sedimentation in reservoirs may also bring positive effects by reducing the sedimentation in the Tonle Sap lake that is believed to be rapidly filling in recent years [118]. This offsetting effect could be especially important if the impacts of climate change cause a substantial increase in sediment yield over the basin [49]. The precise rate of the infilling of the Lake are unknown, but local reports suggest that the areas around the edge of the lake are becoming shallower; Kummu et al. [118] suggest that the lake receives $\sim 5 \mathrm{Mt}$ and $2 \mathrm{Mt}$ sediment from the Mekong and the tributaries, respectively, but only $\sim 1.4 \mathrm{Mt}(20 \%)$ of it returns to the Mekong every year; the $80 \%$ of the sediment load that remains in the lake and its floodplain is equivalent to an average accumulation of $\sim 1.42 \mathrm{~mm} / \mathrm{yr}$ of sediment over the permanent lake area of $2500 \mathrm{~km}^{2}$.

In addition, the Mekong delta is sinking due to human activities $[119,120]$. The net positive contribution of sediment deposition in the Mekong delta at an average rate of 0.3-1.8 mm/year is counterbalancing the sinking of the Delta and offsetting sea level rise [117]; further sinking, sea level rise, and reduction in sediment delivery thus pose a serious threat to the Mekong Delta and exacerbate existing problems. Manh et al. [41] found that hydropower development dominates the changes in floodplain sediment dynamics of the Mekong Delta, while sea level rise has a smaller effect. The floodplains of the Vietnamese Mekong Delta are much more sensitive to the changes compared to the other subsystems of the delta. They suggested that the combination of potential maximum changes due to all drivers can lead to nearly $90 \%$ reduction in delta sedimentation and a $95 \%$ reduction of the sediment reaching the sea.

\section{Hydrological Modeling}

Understanding the hydrological processes in the Mekong basin involves distinguishing physiographic and environmental conditions that drive both dry and wet season flows. While observational precipitation and streamflow data can be used to understand the hydrological responses, models are generally needed to quantify the space-time varying nature of hydrological states and fluxes (e.g., soil moisture, streamflow, ET, TWS, and groundwater recharge). Several global-, regional-, and local-scale hydrological models have been used for both historical analysis and future projections in the Mekong. The primary application of most of these models has been on simulating river flows and assessing the effects of climate change, but some studies have also examined soil moisture and ET while others have assessed the effects of dams on streamflow and sea level rise on coastal groundwater.

Early modeling efforts date back to the 1980s when the Hydro System Seasonal Regulation (HYSSR) model and Massachusetts Institute of Technology River Basin Model (MITSIM) were applied to evaluate reservoir operation at specific locations [15]. The Vietnam River Systems and Plains (VRSAP) model was also developed at a similar time to simulate water flow, tidal effects, and salinity intrusion in the Mekong Delta. The VRSAP model has been continuously updated and improved [121]. Various other water resource models including the MRC's Decision Support Framework (DSF), DHI's MIKE BASIN, and Water Utilization Program-Finnish Environment Institute (WUP-FIN) have been used to assess water resources at basin to sub-basin levels. A detailed review of these models can be found in Johnston and Kummu [15]. We note that most of these models employ water balance schemes that greatly simplify the surface and sub-surface hydrological processes when applied over large regions such as the MRB. Further, the paucity of observed data in the Mekong hinders an extensive calibration and evaluation of these models over the entire basin. 
The semi-distributed land-use runoff process (SLURP) model was used by Kite [122] to simulate the complete hydrological cycle of the Mekong and its tributaries. This study demonstrated that the SLURP model can successfully simulate river flows over the entire Mekong. However, a comparative analysis between SLURP and MIKE SHE models suggested that MIKE SHE performs better across different climate change scenarios in the Mekong. When compared to global hydrologic models such as Mac-PDM.09, the SLURP, MIKE SHE, and SWAT models all perform significantly better, especially in predicting peak flows $[48,123]$. Disparities in simulation capabilities are likely related strongly to difference in algorithms used to estimate potential evapotranspiration. SWAT has been found to simulate the region's hydrology with high accuracy, and is capable of estimating high flow periods within $1 \%$ and low flow periods within 3\% [123]. The VMOD distributed hydrological model has also been used to: examine the likely effects of climate change and reservoir operation on Mekong streamflow over the next 20-30 years [8], estimate the sediment load at different gauging stations along the mainstem Mekong [42], and examine streamflow changes due to the construction of dams from 1960 to 2004 [124]. The Shuttleworth-Wallace (S-W) model was used by Zhou et al. [125] to estimate potential ET (PET) over the Mekong; using the meteorological data from the Climate Research Unit (CRU) TS 2.0 and monthly composite Normalized Difference Vegetation Index (NDVI) from the National Oceanic and Atmospheric Administration (NOAA)-Advanced Very High Resolution Radiometer (AVHRR), they found that the PET averaged over the Mekong ranged from 300 to $2040 \mathrm{~mm}$ (average $1354 \mathrm{~mm}$ ) from 1981 to 2000, with significant seasonal variations that can be linked to changes in leaf area index (LAI).

Macroscale hydrological models with accurate precipitation data and streamflow routing can generally provide accurate simulations of flows through the narrow, deep gorges of Tibetan and Chinese portion of the Upper Mekong basin ( $24 \%$ of the total basin area). However, models are less accurate for the important Lower Mekong basin from Yunnan, China to Tonle Sap Lake in Cambodia since the flood-season flows substantially alter the surface area of the lake [23]. Several such large-scale models have been applied over the Mekong or some global analyses include the MRB. The effects of irrigation water abstraction on surface water and energy fluxes were evaluated using the Variable Infiltration Capacity (VIC) hydrologic model [73], indicating that the volume-based total net irrigation water requirement was about $24 \times 10^{9} \mathrm{~m}^{3} /$ year for 1979-2000 [74]. Other studies have used VIC to examine streamflow and the relative role of precipitation and soil moisture on streamflows (e.g., [65,126]). The VIC model has also been used to simulate the inflow to the existing reservoirs and examine the operating patterns of reservoirs using residence time and flow alteration information [127]. River-floodplain routing models have also been used in the Mekong. For example, Yamazaki et al. [128] applied the global CaMa-Flood hydrodynamic model and highlighted the role of channel bifurcation in realistically simulating the flow and flood patterns in the Mekong Delta. Zhao et al. [129] also used the CaMa-Flood model for global simulations and compared the results of flood peak in the Mekong with a number of other global hydrological models. Simulations from the YHyM model show that Laos contributes the most to the total basin discharge with a 35\% contribution, while Thailand and Cambodia are the next largest contributors with $\sim 18 \%$ each. Therefore, dam development in these countries is expected to have the largest relative impact on the Mekong's hydrologic regime [130].

The Geomorphology-Based Hydrological Model (GBHM) was coupled with a simple reservoir operation model to assess the impacts of climate change and reservoir regulation on flood risk over the LMRB [59]. Hanington et al. [131] evaluated the development and calibration of a fine-scaled quasi-2D hydrodynamic model (IWRM-LXQ) for a portion of the Vietnamese Mekong Delta. The model provided reasonable simulations of low flow and high flood events in both dry and wet seasons where good spatial and temporal data exists, but poor data quality created issues in other areas. Dutta et al. [132] used a model with a 1-D river flow and 2-D surface flow to simulate flood inundation, providing a reasonable agreement with the observed water levels and discharges. By using the SWAT model with inputs from general circulation models (GCMs) Shrestha et al. [49] simulated the effects of climate change on sediment yield in the Nam Ou basin in northern Laos and projected increases 
in discharge and sediment flux during the wet seasons. Numerous other studies have also used SWAT in combination with other models of water resource development (e.g., [46,123]) and 2-D and 3-D hydrodynamics models (e.g., [133]) to study the changing hydrology, sediment yield, reservoir operation, and flooding in the Lower Mekong. Thanapakpawin et al. [134] assessed the hydrologic effects of land use change in the Mae Chaem River; they developed three plausible forest-to-crop expansion scenarios and a crop-to-forest reversal scenario based on the land cover transition from 1989 to 2000 and simulated the hydrologic response using the Distributed Hydrology Soil Vegetation Model (DHSVM). They found that the expansion of highland crop fields affected annual and wet-season water yields compared to a similar expansion in the lowland-midland zone and the downstream sections of the river were sensitive to irrigation diversion. We note that the surface erosion and landslides caused by expanding rural road networks, which could be substantial sources of sediment generation [53], are not taken into account in the aforementioned studies.

\section{Hydrological Impacts of Climate Change}

Climate change is expected to intensify the hydrological cycle [135] by changing the rates and patterns of precipitation and ET, consequently affecting river flows $[136,137]$. The MRB is characterized by significant spatial and temporal variation in precipitation patterns (Figure 5a). As discussed in Section 2, studies have found an increase in precipitation in the Upper Mekong during the latter half of the 20th century but no significant increase in the Lower Mekong. Projections from climate models suggest a significant warming across the basin by the mid and late 21st century but changes in precipitation vary across the basin both in sign and magnitude [138]. When averaged over the entire basin, results from 10 GCMs used in the fifth phase of the Coupled Model Intercomparison Project (CMIP5) indicate that both precipitation and temperature will likely increase by the end of the 21st century (Figure $5 b, c)$.
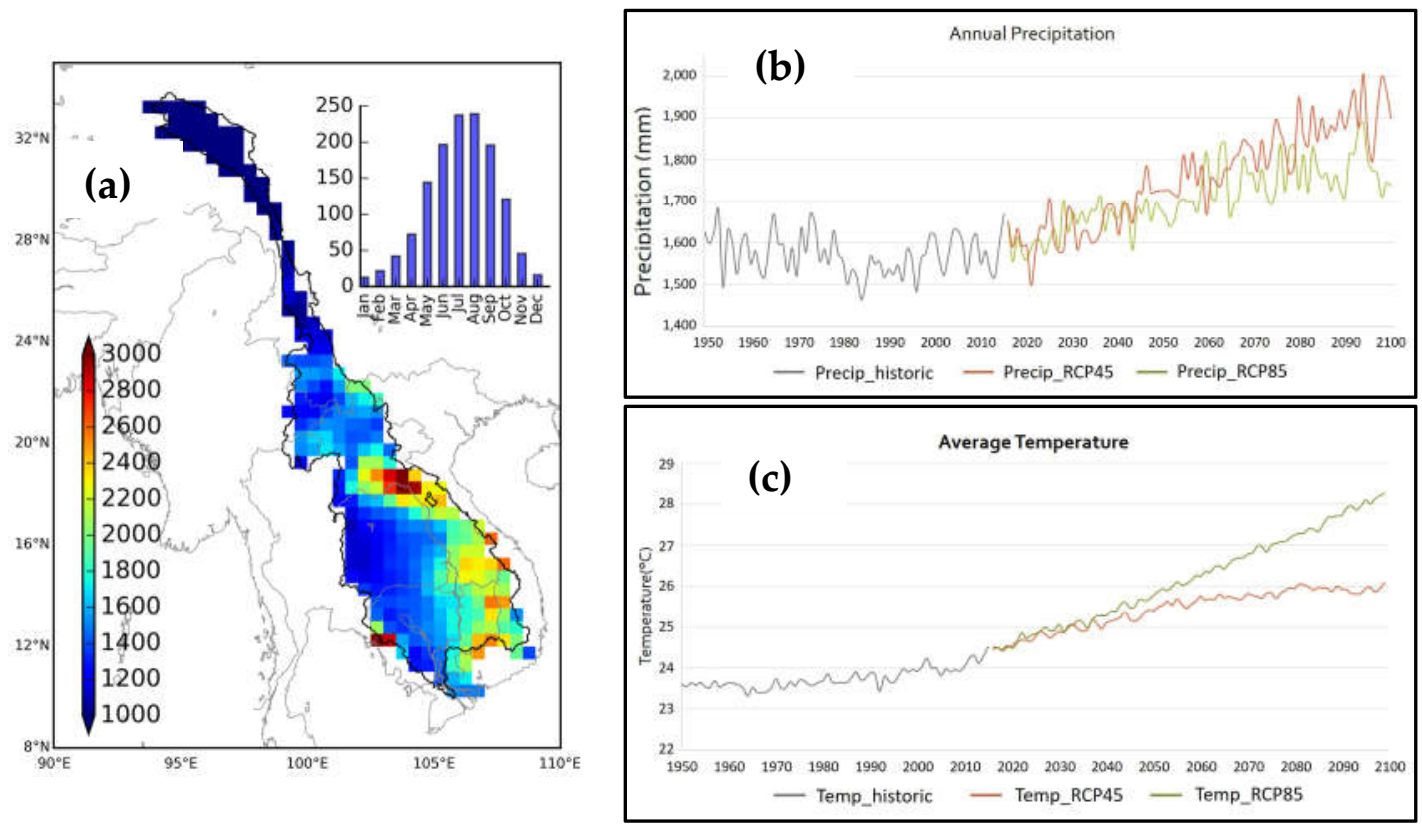

Figure 5. Long-term mean (1901-2010) annual precipitation (in $\mathrm{mm} /$ year) at $0.5^{\circ}$ grids (a) along with the seasonal cycle (bar chart; in mm/month) obtained from the Global Precipitation Climatology Center (GPCC), and time series of basin-averaged annual total precipitation (b) and temperature (c) shown as mean of 10 CMIP5 GCMs for two different representative concentration pathways: RCP4.5 and RCP8.5.

Numerous studies have evaluated hydrologic effects of climate change over the Mekong using projections from GCMs $[130,139,140]$. One of the earliest studies by Nijssen et al. [141] evaluated 
climate change impacts on hydrologic sensitivity in nine large river basins in the world, including the Mekong, based on climate projections from four GCMs. The VIC model was used to estimate changes in streamflow, ET, and moisture storage across these basins, indicating that most mid-latitude and tropical basins showed warmer and somewhat wetter conditions, while increases in annual flow volume were predicted for high-latitude basins. Västilä et al. [139] reported a $4 \%$ increase in annual streamflow and an increase in annual average temperature between $1{ }^{\circ} \mathrm{C}$ and $2{ }^{\circ} \mathrm{C}$ by the $2040 \mathrm{~s}$ in the Mekong using the dynamically downscaled data from the ECHAM4 climate model. Kingston et al. [142] quantified the uncertainty in climate change projections associated with GCM structure and climate sensitivity, as well as from hydrological model parameter specification using pattern scaled GCM scenarios fed into a semi-distributed hydrological model (SLURP). Their results showed a non-linear response of annual river discharge to increasing global mean temperature, ranging from a $5.4 \%$ decrease to $4.5 \%$ increase. Changes in mean monthly river discharge are greater (from $-16 \%$ to $+55 \%$, with greatest decreases in July and August, greatest increases in May and June) due to complex and contrasting intra-basin changes in precipitation, evaporation and snow storage and melt.

A hydrologic analysis of seven GCMs concluded that multi-model assessments are important because of the existing differences in precipitation projections among multiple GCMs [142]. Thompson et al. $[48,143]$ used the climate data from seven GCMs and concluded that inter-GCM precipitation differences are a prominent source of uncertainty compared with potential ET and the choice of hydrological models. Hasson et al. [144] revealed the higher efficacy of CMIP5 GCMs in the Asian monsoon region including the MRB. A frequency analysis of extreme high and low flows in the Mekong projects a reduction in the frequency and magnitude of extremely low flows because of increased flows during dry seasons from five downscaled CMIP5 projections [145]. Further, the multivariate drought risk assessment of Thilakarathe et al. [146] revealed an increase in drought risks in the LMRB. Notably, the Chi-Mun subbasin may experience less drought conditions in the future as this region is expected to experience an increase on average monthly precipitation in most months. However, the same study suggested that the variability in magnitude of precipitation in the LMRB requires adaptation strategies to address future drought risk.

The effects of the Lancang-Jiang cascade of hydropower dams on downstream hydrology was assessed using a hydrological model with a reservoir optimization model [25]. They found that on average this cascade of dams increased the December-May discharge by 34 to $155 \%$ and decreased the July-September discharge by 29 to $36 \%$ at Chiang Saen. Analysis of the impacts of large-scale changes in hydrological response in the LMRB [147] indicate that the majority of catchments $(64 \%)$ exhibited no apparent trends in hydrological response. Lauri et al. [8] evaluated the impact of massive hydropower construction and climate change on the hydrology in the Mekong for the next 20-30 years and found that the associated changes in discharge have more effect on the hydrograph than climate change ( 25 to $160 \%$ higher dry season flows and 5 to $24 \%$ lower flood peaks in Kratie). Using the Japan Meteorological Agency Atmospheric GCM (JMA AGCM) Kiem et al. [130] indicated that most of the sub-basins of the Mekong will experience an increase in the number of wet days by the end of the 21st century (2080-2099), which may result in increased flooding risk but a reduced likelihood of droughts and low-flow periods. Eastham et al. [89] described how the climate and hydrology of the MRB is likely to change by 2030, with projected increase in flood risk and food scarcity, with adverse impacts to the productivity of fisheries.

\section{Summary and Outlook}

In this paper, we provide a detailed review of the existing body of literature on the hydrological, agricultural, and ecological changes in the Mekong River Basin due to large-scale dam construction for hydropower generation and climate change. The review highlights the importance of understanding the coupled human, hydrologic, climate and ecological systems in the Mekong to address the growing regional and global concerns about the adverse hydrological, agricultural, and ecological impacts of the proposed dam construction and projected climate change. Multiple studies have examined 
the historical changes and provided future projections under different scenarios of climate change, socio-economic development, and dam construction. Further, hydrological models have been used to examine the changes in river flow, magnitude and timing of the flood pulse, groundwater, sediment transport, fisheries, and agriculture. However, the emerging scenarios of land use-driven impacts are yet to be fully understood. Importantly, the impacts of many emerging issues including changes in land use due to the expansion of road networks associated with agricultural development and dam construction are ignored in most previous studies. Various international development agencies and organizations, including the Mekong River Commission (MRC) have made enormous contributions to build the knowledge base by recognizing the water, energy and food nexus and their relationship to water quality, sediment transport, fisheries, agriculture, and in-stream ecosystems.

The existing literature provides substantial impetus to study the effects of newly built dams and climate change; however, there has not yet been a comprehensive and holistic analysis of the compounded effects of the hydrologic changes in the upper portion of the basin due to climate change, changes in sediment generation especially in rural sub-basins, operation and management of dams in the middle reaches of the river, along with sea level rise, sediment deposition and flooding in the delta region. We synthesize our key findings from the review into a series of questions that should be addressed by future studies:

(1) While existing and newly built dams can augment basin storage, how do they affect freshwater biodiversity across the basin? What are the compounded effects of expanding basin development and climate change on a broad range of hydrological, agricultural, and ecological systems?

(2) How would the construction of all planned dams affect the high and low flows along the main stem of the Mekong and how will that affect irrigation, downstream agriculture, and in-stream processes? Will the altered wet- and dry-season flows due to dam regulation bring positive benefits to the downstream reach?

(3) How will the reduction in floodplain inundation and associated changes in recharge due to regulated flows affect groundwater systems in the Tonle Sap Lake and Mekong Delta regions? How will coastal groundwater systems with widespread salinity intrusion fare in the future under the dual pressure of rising sea levels due to climate change and lowering water tables due to hydrologic changes in the upstream portions of the basin?

(4) Are there ways to develop and manage hydropower in the Mekong to minimize the adverse impacts on the fisheries, sediment transport, and agriculture while considering the potential effects of climate change?

Addressing these questions requires a holistic study that brings together various climatic and human drivers of change into a consistent framework to examine the potential changes in the water cycle, land use and land cover, water and other infrastructure, agricultural systems, food productivity, and ecosystem services, as well as the dynamic interactions and feedback among these intricately intertwined natural-human systems. Since the goal is to provide realistic future projections, such a framework should employ integrated hydrological, agricultural, and ecological models driven by climate projections from general circulation models (GCMs) and various scenarios of socio-economic growth and water infrastructure development. It is also crucial that these integrated frameworks be developed and applied over the entire river basin to examine the effects of distant but connected systems. In conclusion, studies investigating the impacts of large hydropower dam projects and climate change on the hydro-agro-ecological systems in the Mekong will be essential to effectively manage this important river basin.

Acknowledgments: This work was supported in part by NASA under the award 80NSSC17K0259. We thank the Research Program on Water, Land, and Ecosystems (WLE), Greater Mekong for providing the dam database used in Figure 1, and Zihan Lin for the data used in Figure 4.

Conflicts of Interest: The authors declare no conflicts of interest. 


\section{References}

1. Mekong River Commission (MRC). Overview of the Hydrology of the Mekong Basin; MRC: Vientiane, Laos, 2005; p. 73.

2. Ziv, G.; Baran, E.; Nam, S.; Rodríguez-Iturbe, I.; Levin, S.A. Trading-off fish biodiversity, food security, and hydropower in the Mekong river basin. Proc. Natl. Acad. Sci. USA 2012, 109, 5609-5614. [CrossRef] [PubMed]

3. Mekong River Commission (MRC). Mekong River Commission: State of the Basin Report 2010; MRC: Vientiane, Laos, 2010.

4. Winemiller, K.O.; McIntyre, P.B.; Castello, L.; Fluet-Chouinard, E.; Giarrizzo, T.; Nam, S.; Baird, I.G.; Darwall, W.; Lujan, N.K.; Harrison, I.; et al. Balancing hydropower and biodiversity in the Amazon, Congo, and Mekong. Science 2016, 351, 128-129. [CrossRef] [PubMed]

5. Grumbine, R.E.; Xu, J. Mekong hydropower development. Science 2011, 332, 178-179. [CrossRef] [PubMed]

6. Nilsson, C.; Reidy, C.A.; Dynesius, M.; Revenga, C. Fragmentation and flow regulation of the world's large river systems. Science 2005, 308, 405-408. [CrossRef] [PubMed]

7. Fredén, F. Impacts of Dams on Lowland Agriculture in the Mekong River Catchment; Lunds Universitets Naturgeografiska Institution-Seminarieuppsatser: Lund, Sweden, 2011.

8. Lauri, H.; de Moel, H.; Ward, P.J.; Räsänen, T.A.; Keskinen, M.; Kummu, M. Future changes in Mekong river hydrology: Impact of climate change and reservoir operation on discharge. Hydrol. Earth Syst. Sci. 2012, 16, 4603-4619. [CrossRef]

9. Stone, R. Mayhem on the Mekong. Science 2011, 333, 814-818. [CrossRef] [PubMed]

10. Keskinen, M.; Kummu, M.; Käkönen, M.; Varis, O. Mekong at the crossroads: Next steps for impact assessment of large dams. Ambio 2012, 41, 319. [CrossRef] [PubMed]

11. Salmon, J.M.; Friedl, M.A.; Frolking, S.; Wisser, D.; Douglas, E.M. Global rain-fed, irrigated, and paddy croplands: A new high resolution map derived from remote sensing, crop inventories and climate data. Int. J. Appl. Earth Observ. Geoinf. 2015, 38, 321-334. [CrossRef]

12. Adamson, P. Hydrological and water resources modelling in the Mekong region: A brief overview. Explor. Water Futures Together Mekong Reg. Waters Dialogue 2006, 69-74.

13. Mekong River Commission (MRC). Assessment of Basin-Wide Development Scenarios-Main Report; MRC: Vientiane, Laos, 2010.

14. Lutz, A.; Immerzeel, W.; Shrestha, A.; Bierkens, M. Consistent increase in high Asia's runoff due to increasing glacier melt and precipitation. Nat. Clim. Chang. 2014, 4, 587-592. [CrossRef]

15. Johnston, R.; Kummu, M. Water resource models in the Mekong basin: A review. Water Resour. Manag. 2012, 26, 429-455. [CrossRef]

16. Nesbitt, H.; Johnston, R.; Solieng, M. Mekong river water: Will river flows meet future agriculture needs in the lower Mekong basin? Water Agric. 2004, 116, 86-104.

17. Stone, R. Dam-Building Threatens Mekong Fisheries. Science 2016, 354, 1084-1085. [CrossRef] [PubMed]

18. Orr, S.; Pittock, J.; Chapagain, A.; Dumaresq, D. Dams on the Mekong river: Lost fish protein and the implications for land and water resources. Glob. Environ. Chang. 2012, 22, 925-932. [CrossRef]

19. Cosslett, T.L.; Cosslett, P.D. Sustainable Development of Rice and Water Resources in Mainland Southeast Asia and Mekong River Basin; Springer: Berlin, Germany, 2017.

20. Smajgl, A.; Toan, T.Q.; Nhan, D.K.; Ward, J.; Trung, N.H.; Tri, L.Q.; Tri, V.P.D.; Vu, P.T. Responding to rising sea levels in the Mekong delta. Nat. Clim. Chang. 2015, 5, 167-174. [CrossRef]

21. Keskinen, M.; Someth, P.; Salmivaara, A.; Kummu, M. Water-energy-food nexus in a transboundary river basin: The case of Tonle sap lake, Mekong river basin. Water 2015, 7, 5416-5436. [CrossRef]

22. Smajgl, A.; Ward, J.; Pluschke, L. The water-food-energy nexus-realising a new paradigm. J. Hydrol. 2016, 533, 533-540. [CrossRef]

23. Kummu, M.; Sarkkula, J. Impact of the Mekong river flow alteration on the Tonle sap flood pulse. Ambio 2008, 37, 185-192. [CrossRef]

24. Li, D.; Long, D.; Zhao, J.; Lu, H.; Hong, Y. Observed changes in flow regimes in the Mekong river basin. J. Hydrol. 2017, 551, 217-232. [CrossRef]

25. Räsänen, T.A.; Koponen, J.; Lauri, H.; Kummu, M. Downstream hydrological impacts of hydropower development in the upper Mekong basin. Water Resour. Manag. 2012, 26, 3495-3513. [CrossRef] 
26. Fan, H.; He, D. Temperature and precipitation variability and its effects on streamflow in the upstream regions of the Lancang-Mekong and Nu-Salween rivers. J. Hydrometeorol. 2015, 16, 2248-2263. [CrossRef]

27. Xue, Z.; Liu, J.P.; Ge, Q. Changes in hydrology and sediment delivery of the Mekong river in the last 50 years: Connection to damming, monsoon, and enso. Earth Surf. Process. Landf. 2011, 36, 296-308. [CrossRef]

28. Hapuarachchi, H.A.P.; Takeuchi, K.; Zhou, M.; Kiem, A.S.; Georgievski, M.; Magome, J.; Ishidaira, H. Investigation of the Mekong river basin hydrology for 1980-2000 using the YHYM. Hydrol. Process. 2008, 22, 1246-1256. [CrossRef]

29. Li, S.; He, D. Water level response to hydropower development in the upper Mekong river. Ambio 2008, 37, 170-176. [CrossRef]

30. Delgado, J.; Merz, B.; Apel, H. Flood trends and variability in the Mekong river. Hydrol. Earth Syst. Sci. 2010, 11, 407-418. [CrossRef]

31. Ward, P.J.; Beets, W.; Bouwer, L.M.; Aerts, J.C.J.H.; Renssen, H. Sensitivity of river discharge to Enso. Geophys. Res. Lett. 2010, 37, 1-6. [CrossRef]

32. Räsänen, T.A.; Kummu, M. Spatiotemporal influences of Enso on precipitation and flood pulse in the Mekong river basin. J. Hydrol. 2013, 476, 154-168. [CrossRef]

33. Delgado, J.M.; Merz, B.; Apel, H. A climate-flood link for the lower Mekong river. Hydrol. Earth Syst. Sci. 2012, 16, 1533-1541. [CrossRef]

34. ICEM. MRC Strategic Environmental Assessment (SEA) of Hydropower on the Mekong Mainstream, Hanoi, Viet Nam; MRC: Hanoi, Viet Nam, 2010; p. 197.

35. International Hydropower Association (IHA). Hydropower Status Report 2016; International Hydropower Association: London, UK, 2016; p. 41.

36. Pholsena, S.; Phonekeo, D. Lao Hydropower Potential and Policy in the GMS Context; United Nations Symposium on Hydropower and Sustainable Development, Beijing International Convention Centre: Beijing, China, 2004; pp. 27-29.

37. Bartle, A. Hydropower potential and development activities. Energy Policy 2002, 30, 1231-1239. [CrossRef]

38. Magee, D. The dragon upstream: China's role in Lancang-Mekong development. In Politics and Development in a Transboundary Watershed; Springer: Berlin, Germany, 2011; pp. 171-193.

39. International-Rivers. The Xayaburi Dam: A Looming Threat to the Mekong River; International Rivers: Berkeley, CA, USA, 2011; pp. 1-4.

40. Kummu, M.; Lu, X.X.; Wang, J.J.; Varis, O. Basin-wide sediment trapping efficiency of emerging reservoirs along the Mekong. Geomorphology 2010, 119, 181-197. [CrossRef]

41. Manh, N.V.; Dung, N.V.; Hung, N.N.; Kummu, M.; Merz, B.; Apel, H. Future sediment dynamics in the Mekong delta floodplains: Impacts of hydropower development, climate change and sea level rise. Glob. Planet. Chang. 2015, 127, 22-33. [CrossRef]

42. Darby, S.E.; Hackney, C.R.; Leyland, J.; Kummu, M.; Lauri, H.; Parsons, D.R.; Best, J.L.; Nicholas, A.P.; Aalto, R. Fluvial sediment supply to a mega-delta reduced by shifting tropical-cyclone activity. Nature 2016, 539, 276-279. [CrossRef] [PubMed]

43. Kummu, M.; Varis, O. Sediment-related impacts due to upstream reservoir trapping, the lower Mekong river. Geomorphology 2007, 85, 275-293. [CrossRef]

44. Sidle, R.C.; Ziegler, A.D. The dilemma of mountain roads. Nat. Geosci. 2012, 5, 437. [CrossRef]

45. International-Rivers. The Don Sahong Dam: Gambling with Mekong Food Security and Livelihoods; International Rivers: Berkeley, CA, USA, 2015; pp. 1-4.

46. Arias, M.E.; Piman, T.; Lauri, H.; Cochrane, T.A.; Kummu, M. Dams on Mekong tributaries as significant contributors of hydrological alterations to the Tonle sap floodplain in Cambodia. Hydrol. Earth Syst. Sci. 2014, 18, 5303-5315. [CrossRef]

47. Arias, M.E.; Cochrane, T.A.; Piman, T.; Kummu, M.; Caruso, B.S.; Killeen, T.J. Quantifying changes in flooding and habitats in the Tonle sap lake (Cambodia) caused by water infrastructure development and climate change in the Mekong basin. J. Environ. Manag. 2012, 112, 53-66. [CrossRef] [PubMed]

48. Thompson, J.R.; Green, A.J.; Kingston, D.G.; Gosling, S.N. Assessment of uncertainty in river flow projections for the Mekong river using multiple GCMS and hydrological models. J. Hydrol. 2013, 486, 1-30. [CrossRef]

49. Shrestha, B.; Babel, M.S.; Maskey, S.; van Griensven, A.; Uhlenbrook, S.; Green, A.; Akkharath, I. Impact of climate change on sediment yield in the Mekong river basin: A case study of the Nam OU Basin, Lao PDR. Hydrol. Earth Syst. Sci. 2013, 17, 1-20. [CrossRef] 
50. Erban, L.E.; Gorelick, S.M.; Zebker, H.A. Groundwater extraction, land subsidence, and sea-level rise in the Mekong delta, Vietnam. Environ. Res. Lett. 2014, 9, 084010. [CrossRef]

51. Merola, R.B.; Hien, T.T.; Quyen, D.T.T.; Vengosh, A. Arsenic exposure to drinking water in the Mekong delta. Sci. Total Environ. 2015, 511, 544-552. [CrossRef] [PubMed]

52. Intralawan, A.; Wood, D.; Frankel, R. Economic Evaluation of Hydropower Projects in the Lower Mekong Basin; Mae Fah Luang University: Chiang Rai, Thailand, 2017; p. 21.

53. Sidle, R.C.; Furuichi, T.; Kono, Y. Unprecedented rates of landslide and surface erosion along a newly constructed road in Yunnan, China. Natl. Hazards 2011, 57, 313-326. [CrossRef]

54. Sidle, R.C.; Ghestem, M.; Stokes, A. Epic landslide erosion from mountain roads in Yunnan, China-Challenges for sustainable development. Natl. Hazards Earth Syst. Sci. 2014, 14, 3093-3104. [CrossRef]

55. Imaizumi, F.; Sidle, R.C. Linkage of sediment supply and transport processes in Miyagawa Dam Catchment, Japan. J. Geophys. Res. Earth Surf. 2007, 112. [CrossRef]

56. Pokhrel, Y.; Hanasaki, N.; Koirala, S.; Cho, J.; Yeh, P.J.-F.; Kim, H.; Kanae, S.; Oki, T. Incorporating anthropogenic water regulation modules into a land surface model. J. Hydrometeorol. 2012, 13, 255-269. [CrossRef]

57. Felfelani, F.; Wada, Y.; Longuevergne, L.; Pokhrel, Y.N. Natural and human-induced terrestrial water storage change: A global analysis using hydrological models and grace. J. Hydrol. 2017, 553, 105-118. [CrossRef]

58. Pokhrel, Y.N.; Hanasaki, N.; Yeh, P.J.-F.; Yamada, T.J.; Kanae, S.; Oki, T. Model estimates of sea-level change due to anthropogenic impacts on terrestrial water storage. Nat. Geosci. 2012, 5, 389-392. [CrossRef]

59. Wang, W.; Lu, H.; Ruby Leung, L.; Li, H.Y.; Zhao, J.; Tian, F.; Yang, K.; Sothea, K. Dam construction in lancang-Mekong river basin could mitigate future flood risk from warming-Induced intensified rainfall. Geophys. Res. Lett. 2017, 44. [CrossRef]

60. Veldkamp, T.I.E.; Wada, Y.; Aerts, J.C.J.H.; Döll, P.; Gosling, S.N.; Liu, J.; Masaki, Y.; Oki, T.; Ostberg, S.; Pokhrel, Y.; et al. Water scarcity hotspots travel downstream due to human interventions in the 20th and 21st century. Nat. Commun. 2017, 8, 15697.

61. Sabo, J.; Ruhi, A.; Holtgrieve, G.; Elliott, V.; Arias, M.; Ngor, P.B.; Räsänen, T.; Nam, S. Designing river flows to improve food security futures in the lower Mekong basin. Science 2017, 358, eaao1053. [CrossRef] [PubMed]

62. Houghton, R.A. The worldwide extent of land-use change. BioScience 1994, 44, 305-313. [CrossRef]

63. Flint, E.P.; Richards, J.F. Historical analysis of changes in land use and carbon stock of vegetation in South and Southeast Asia. Can. J. For. Res. 1991, 21, 91-110. [CrossRef]

64. Richards, J.F.; Flint, E.P. A century of land-use change in South and Southeast Asia. In Effects of Land-Use Change on Atmospheric $\mathrm{CO}_{2}$ Concentrations: South and Southeast Asia as a Case Study; Dale, V.H., Ed.; Springer: New York, NY, USA, 1994; pp. 15-66.

65. Costa-Cabral, M.C.; Richey, J.E.; Goteti, G.; Lettenmaier, D.P.; Feldkötter, C.; Snidvongs, A. Landscape structure and use, climate, and water movement in the Mekong river basin. Hydrol. Process. 2008, 22, 1731-1746. [CrossRef]

66. Arias, M.E.; Cochrane, T.A.; Norton, D.; Killeen, T.J.; Khon, P. The flood pulse as the underlying driver of vegetation in the largest wetland and fishery of the Mekong basin. Ambio 2013, 42, 864-876. [CrossRef] [PubMed]

67. Lin, Z.; Qi, J. Hydro-dam-A nature-based solution or an ecological problem: The fate of the Tonlé sap lake. Environ. Res. 2017, 158, 24-32. [CrossRef] [PubMed]

68. Siebert, S.; Kummu, M.; Porkka, M.; Döll, P.; Ramankutty, N.; Scanlon, B.R. A global data set of the extent of irrigated land from 1900 to 2005. Hydrol. Earth Syst. Sci. 2015, 19, 1521-1545. [CrossRef]

69. Mekong River Commission (MRC). Regional Irrigation Sector Review for Joint Basin Planning Process; MRC: Vientiane, Laos, 2009; p. 59.

70. Mekong River Commission (MRC). Water Used for Agriculture in the Lower Mekong River Basin, Discussion Paper; MRC: Vientiane, Laos, 2005; p. 66.

71. Levis, S. Modeling vegetation and land use in models of the earth system. WIRES Clim. Chang. 2010, 1, 840-856. [CrossRef]

72. Pokhrel, Y.N.; Felfelani, F.; Shin, S.; Yamada, T.J.; Satoh, Y. Modeling large-scale human alteration of land surface hydrology and climate. Geosci. Lett. 2017, 4, 10. [CrossRef] 
73. Haddeland, I.; Lettenmaier, D.P.; Skaugen, T. Effects of irrigation on the water and energy balances of the Colorado and Mekong river basins. J. Hydrol. 2006, 324, 210-223. [CrossRef]

74. Tatsumi, K.; Yamashiki, Y. Effect of irrigation water withdrawals on water and energy balance in the Mekong river basin using an improved VIC land surface model with fewer calibration parameters. Agric. Water Manag. 2015, 159, 92-106. [CrossRef]

75. Sridhar, V. Tracking the influence of irrigation on land surface fluxes and boundary layer climatology. J. Contemp. Water Res. Educ. 2013, 152, 79-93. [CrossRef]

76. Sridhar, V.; Anderson, K. Human-induced modifications to boundary layer fluxes and their water management implications in a Changing climate. Agric. For. Meteorol. 2017, 234, 66-79. [CrossRef]

77. Homdee, T.; Pongput, K.; Kanae, S. Impacts of land cover changes on hydrologic responses: A case study of Chi River Basin, Thailand. J. Jpn. Soc. Civ. Eng. Ser. B1 2011,67, I_31-I_36. [CrossRef]

78. Dudgeon, D. Large-scale hydrological changes in tropical Asia: Prospects for riverine biodiversity: The construction of large dams will have an impact on the biodiversity of tropical Asian rivers and their associated wetlands. BioScience 2000, 50, 793-806. [CrossRef]

79. Le, T.V.H.; Nguyen, H.N.; Wolanski, E.; Tran, T.C.; Haruyama, S. The combined impact on the flooding in Vietnam's Mekong river delta of local man-made structures, sea level rise, and dams upstream in the river catchment. Estuar. Coast. Shelf Sci. 2007, 71, 110-116. [CrossRef]

80. Piman, T.; Cochrane, T.A.; Arias, M.E.; Green, A.; Dat, N.D. Assessment of flow changes from hydropower development and operations in Sekong, Sesan, and Srepok rivers of the Mekong basin. J. Water Resour. Plan. Manag. 2013, 139, 723-732. [CrossRef]

81. Ty, T.V.; Sunada, K.; Ichikawa, Y. A spatial impact assessment of human-induced intervention on hydrological regimes: A case study in the upper Srepok river basin, central highlands of Vietnam. Int. J. River Basin Manag. 2011, 9, 103-116. [CrossRef]

82. Ty, T.V.; Sunada, K.; Ichikawa, Y.; Oishi, S. Scenario-based impact assessment of land use/cover and climate changes on water resources and demand: A case study in the Srepok river basin, Vietnam-Cambodia. Water Resour. Manag. 2012, 26, 1387-1407. [CrossRef]

83. Wada, Y.; Bierkens, M.F.; De Roo, A.; Dirmeyer, P.A.; Famiglietti, J.S.; Hanasaki, N.; Konar, M.; Liu, J.; Schmied, H.M.; Oki, T. Human-water interface in hydrological modelling: Current status and future directions. Hydrol. Earth Syst. Sci. 2017, 21, 4169. [CrossRef]

84. Wiley, M.; Hyndman, D.; Pijanowski, B.; Kendall, A.; Riseng, C.; Rutherford, E.; Cheng, S.; Carlson, M.; Tyler, J.; Stevenson, R. A multi-modeling approach to evaluating climate and land use change impacts in a great lakes river basin. Hydrobiologia 2010, 657, 243-262. [CrossRef]

85. Pokhrel, Y.N.; Hanasaki, N.; Wada, Y.; Kim, H. Recent progresses in incorporating human land-water management into global land surface models toward their integration into earth system models. WIREs Water 2016, 3, 548-574. [CrossRef]

86. Hanasaki, N.; Yoshikawa, S.; Pokhrel, Y.; Kanae, S. A global hydrological simulation to specify the sources of water used by humans. Hydrol. Earth Syst. Sci. 2018, 22, 789. [CrossRef]

87. Frenken, K. Irrigation in Southern and Eastern Asia in Figures: Aquastat Survey, 2011; Food and Agricultural Organization FAO: Rome, Italy, 2011; p. 512.

88. Pokhrel, Y.N.; Koirala, S.; Yeh, P.J.-F.; Hanasaki, N.; Longuevergne, L.; Kanae, S.; Oki, T. Incorporation of groundwater pumping in a global land surface model with the representation of human impacts. Water Resour. Res. 2015, 51, 78-96. [CrossRef]

89. Eastham, J.; Mpelasoka, F.; Mainuddin, M.; Ticehurst, C.; Dyce, P.; Hodgson, G.; Ali, R.; Kirby, M. Mekong River Basin Water Resources Assessment: Impacts of Climate Change; Commonwealth Scientific and Industrial Research Organisation (CSIRO): Perth, Australia, 2008.

90. Ha, K.; Ngoc, N.T.M.; Lee, E.; Jayakumar, R. Current Status and Issues of Groundwater in the Mekong River Basin; Korea Institute of Geoscience and Mineral Resources (KIGAM): Bangkok, Thailand, 2015; p. 121.

91. Erban, L.E.; Gorelick, S.M.; Zebker, H.A.; Fendorf, S. Release of arsenic to deep groundwater in the Mekong delta, vietnam, linked to pumping-induced land subsidence. Proc. Natl. Acad. Sci. USA 2013, 110, 13751-13756. [CrossRef] [PubMed]

92. Wagner, F.; Tran, V.B.; Renaud, F.G. Groundwater resources in the Mekong delta: Availability, utilization and risks. In The Mekong Delta System; Springer: Berlin, Germany, 2012; pp. 201-220. 
93. Wada, Y.; van Beek, L.P.H.; van Kempen, C.M.; Reckman, J.W.T.M.; Vasak, S.; Bierkens, M.F.P. Global depletion of groundwater resources. Geophys. Res. Lett. 2010, 37, L20402. [CrossRef]

94. IUCN. Groundwater in the Mekong Delta; Ministry of Foreign Affairs of Finland: Helsinki, Finland, $2011 ;$ p. 12.

95. Minderhoud, P.; Erkens, G.; Pham, V.; Bui, V.; Erban, L.; Kooi, H.; Stouthamer, E. Impacts of 25 years of groundwater extraction on subsidence in the Mekong delta, Vietnam. Environ. Res. Lett. 2017, 12, 064006. [CrossRef]

96. White, I. Water Management in the Mekong Delta: Changes, Conflicts and Opportunities; UNESCO: Paris, France, 2002.

97. Ghassemi, F.; Brennan, D. An Evaluation of the Sustainability of Farming Systems in the Brackish Water Region of the Mekong Delta; Resource Profile Subproject: Summary Report; Australian Centre for International Agricultural Research: Canberra, Australia, 2000.

98. Fendorf, S.; Michael, H.A.; van Geen, A. Spatial and temporal variations of groundwater arsenic in South and Southeast Asia. Science 2010, 328, 1123-1127. [CrossRef] [PubMed]

99. Bear, J. Conceptual and mathematical modeling. In Seawater Intrusion in Coastal Aquifers—Concepts, Methods and Practices; Springer: Berlin, Germany, 1999; pp. 127-161.

100. Buschmann, J.; Berg, M.; Stengel, C.; Sampson, M.L. Arsenic and manganese contamination of drinking water resources in Cambodia: Coincidence of risk areas with low relief topography. Environ. Sci. Technol. 2007, 41, 2146-2152. [CrossRef] [PubMed]

101. Buschmann, J.; Berg, M.; Stengel, C.; Winkel, L.; Sampson, M.L.; Trang, P.T.K.; Viet, P.H. Contamination of drinking water resources in the Mekong delta floodplains: Arsenic and other trace metals pose serious health risks to population. Environ. Int. 2008, 34, 756-764. [CrossRef] [PubMed]

102. Buschmann, J.; Berg, M. Impact of sulfate reduction on the scale of arsenic contamination in groundwater of the Mekong, Bengal and Red river deltas. Appl. Geochem. 2009, 24, 1278-1286. [CrossRef]

103. Junk, W. The flood pulse concept of large rivers: Learning from the tropics. Large Rivers 1999, 11, $261-280$. [CrossRef]

104. Kummu, M.; Tes, S.; Yin, S.; Adamson, P.; Józsa, J.; Koponen, J.; Richey, J.; Sarkkula, J. Water balance analysis for the Tonle Sap Lake-Floodplain system. Hydrol. Process. 2014, 28, 1722-1733. [CrossRef]

105. Baran, E.; Myschowoda, C. Dams and fisheries in the Mekong basin. Aquat. Ecosyst. Health Manag. 2009, 12, 227-234. [CrossRef]

106. Bonheur, N.; Lane, B.D. Natural resources management for human security in Cambodia's Tonle sap biosphere reserve. Environ. Sci. Policy 2002, 5, 33-41. [CrossRef]

107. Frappart, F.; Minh, K.D.; L'Hermitte, J.; Cazenave, A.; Ramillien, G.; Toan, T.L.; Mognard-Campbell, N. Water volume change in the lower Mekong from satellite altimetry and imagery data. Geophys. J. Int. 2006, 167, 570-584. [CrossRef]

108. Inomata, H.; Fukami, K. Restoration of historical hydrological data of Tonle sap lake and its surrounding areas. Hydrol. Process. 2008, 22, 1337-1350. [CrossRef]

109. Milliman, J.D.; Meade, R.H. World-wide delivery of river sediment to the oceans. J. Geol. 1983, 91, 1-21. [CrossRef]

110. Milliman, J.D.; Syvitski, J.P. Geomorphic/tectonic control of sediment discharge to the ocean: The importance of small mountainous rivers. J. Geol. 1992, 100, 525-544. [CrossRef]

111. Syvitski, J.P.M.; Milliman, J.D. Geology, geography, and humans battle for dominance over the delivery of fluvial sediment to the coastal ocean. J. Geol. 2007, 115, 1-19. [CrossRef]

112. Walling, D.E. The changing sediment load of the Mekong river. Ambio 2008, 37, 150-157. [CrossRef]

113. Gupta, A.; Liew, S.C. The Mekong from satellite imagery: A quick look at a large river. Geomorphology 2007, 85, 259-274. [CrossRef]

114. Sidle, R.C.; Sasaki, S.; Otsuki, M.; Noguchi, S.; Rahim Nik, A. Sediment pathways in a tropical forest: Effects of logging roads and skid trails. Hydrol. Process. 2004, 18, 703-720. [CrossRef]

115. Cramb, R.A.; Colfer, C.J.P.; Dressler, W.; Laungaramsri, P.; Le, Q.T.; Mulyoutami, E.; Peluso, N.L.; Wadley, R.L. Swidden transformations and rural livelihoods in southeast Asia. Hum. Ecol. 2009, 37, 323-346. [CrossRef]

116. Kondolf, G.; Rubin, Z.; Minear, J. Dams on the Mekong: Cumulative sediment starvation. Water Resour. Res. 2014, 50, 5158-5169. [CrossRef]

117. Manh, N.V.; Dung, N.V.; Hung, N.N.; Merz, B.; Apel, H. Large-scale suspended sediment transport and sediment deposition in the Mekong delta. Hydrol. Earth Syst. Sci. 2014, 18, 3033-3053. [CrossRef] 
118. Kummu, M.; Penny, D.; Sarkkula, J.; Koponen, J. Sediment: Curse or blessing for Tonle sap lake? Ambio 2008, 37, 158-163. [CrossRef]

119. Syvitski, J.P.; Kettner, A.J.; Overeem, I.; Hutton, E.W.; Hannon, M.T.; Brakenridge, G.R.; Day, J.; Vörösmarty, C.; Saito, Y.; Giosan, L. Sinking deltas due to human activities. Nat. Geosci. 2009, 2, 681-686. [CrossRef]

120. Syvitski, J.; Higgins, S. Going under: The world's sinking deltas. New Sci. 2012, 216, 40-43. [CrossRef]

121. Hoanh, C.T.; Phong, N.; Gowing, J.; Tuong, T.; Ngoc, N.; Hien, N. Hydraulic and water quality modeling: A tool for managing land use conflicts in inland coastal zones. Water Policy 2009, 11, 106-120. [CrossRef]

122. Kite, G. Modelling the Mekong: Hydrological simulation for environmental impact studies. J. Hydrol. 2001, 253, 1-13. [CrossRef]

123. Rossi, C.; Srinivasan, R.; Jirayoot, K.; Le Duc, T.; Souvannabouth, P.; Binh, N.; Gassman, P. Hydrologic evaluation of the lower Mekong river basin with the soil and water assessment tool model. Int. Agric. Eng. J. $2009,18,1$.

124. Räsänen, T.A.; Someth, P.; Lauri, H.; Koponen, J.; Sarkkula, J.; Kummu, M. Observed river discharge changes due to hydropower operations in the upper Mekong basin. J. Hydrol. 2017, 545, 28-41. [CrossRef]

125. Zhou, M.; Ishidaira, H.; Hapuarachchi, H.; Magome, J.; Kiem, A.; Takeuchi, K. Estimating potential evapotranspiration using Shuttleworth-Wallace model and NOAA-AVHRR NDVI data to feed a distributed hydrological model over the Mekong river basin. J. Hydrol. 2006, 327, 151-173. [CrossRef]

126. Jayawardena, A.; Mahanama, S. Meso-scale hydrological modeling: Application to Mekong and Chao Phraya basins. J. Hydrol. Eng. 2002, 7, 12-26. [CrossRef]

127. Bonnema, M.; Hossain, F. Inferring reservoir operating patterns across the Mekong basin using only space observations. Water Resour. Res. 2017, 53, 3791-3810. [CrossRef]

128. Yamazaki, D.; Sato, T.; Kanae, S.; Hirabayashi, Y.; Bates, P.D. Regional flood dynamics in a bifurcating mega delta simulated in a global river model. Geophys. Res. Lett. 2014, 41, 3127-3135. [CrossRef]

129. Zhao, F.; Veldkamp, T.I.; Frieler, K.; Schewe, J.; Ostberg, S.; Willner, S.; Schauberger, B.; Gosling, S.N.; Schmied, H.M.; Portmann, F.T.; et al. The critical role of the routing scheme in simulating peak river discharge in global hydrological models. Environ. Res. Lett. 2017, 12, 075003. [CrossRef]

130. Kiem, A.S.; Ishidaira, H.; Hapuarachchi, H.P.; Zhou, M.C.; Hirabayashi, Y.; Takeuchi, K. Future hydroclimatology of the Mekong river basin simulated using the high-resolution Japan meteorological agency (JMA) AGCM. Hydrol. Process. 2008, 22, 1382-1394. [CrossRef]

131. Hanington, P.; To, Q.T.; Van, P.D.T.; Doan, N.A.V.; Kiem, A.S. A hydrological model for interprovincial water resource planning and management: A case study in the long Xuyen quadrangle, Mekong delta, Vietnam. J. Hydrol. 2017, 547, 1-9. [CrossRef]

132. Dutta, D.; Alam, J.; Umeda, K.; Hayashi, M.; Hironaka, S. A two-dimensional hydrodynamic model for flood inundation simulation: A case study in the lower Mekong river basin. Hydrol. Process. 2007, 21, 1223-1237. [CrossRef]

133. Arias, M.E.; Cochrane, T.A.; Kummu, M.; Lauri, H.; Holtgrieve, G.W.; Koponen, J.; Piman, T. Impacts of hydropower and climate change on drivers of ecological productivity of southeast Asia's most important wetland. Ecol. Model. 2014, 272, 252-263. [CrossRef]

134. Thanapakpawin, P.; Richey, J.; Thomas, D.; Rodda, S.; Campbell, B.; Logsdon, M. Effects of landuse change on the hydrologic regime of the Mae Chaem river basin, NW Thailand. J. Hydrol. 2007, 334, 215-230. [CrossRef]

135. Huntington, T.G. Evidence for intensification of the global water cycle: Review and synthesis. J. Hydrol. 2006, 319, 83-95. [CrossRef]

136. Milly, P.C.; Dunne, K.A.; Vecchia, A.V. Global pattern of trends in streamflow and water availability in a changing climate. Nature 2005, 438, 347-350. [CrossRef] [PubMed]

137. Oki, T.; Kanae, S. Global hydrological cycles and world water resources. Science 2006, 313, $1068-1072$. [CrossRef] [PubMed]

138. IPCC. Climate Change 2014-Impacts, Adaptation and Vulnerability: Regional Aspects; Cambridge University Press: Cambridge, UK, 2014.

139. Västilä, K.; Kummu, M.; Sangmanee, C.; Chinvanno, S. Modelling climate change impacts on the flood pulse in the lower Mekong floodplains. J. Water Clim. Chang. 2010, 1, 67-86. [CrossRef]

140. Hoanh, C.T.; Jirayoot, K.; Lacombe, G.; Srinetr, V. Impacts of Climate Change and Development on Mekong Flow Regimes. First Assessment-2009; International Water Management Institute: Colombo, Sri Lanka, 2010. 
141. Nijssen, B.; O'donnell, G.M.; Hamlet, A.F.; Lettenmaier, D.P. Hydrologic sensitivity of global rivers to climate change. Clim. Chang. 2001, 50, 143-175. [CrossRef]

142. Kingston, D.; Thompson, J.R.; Kite, G. Uncertainty in climate change projections of discharge for the Mekong river basin. Hydrol. Earth Syst. Sci. 2011, 15, 1459. [CrossRef]

143. Thompson, J.; Green, A.; Kingston, D. Potential evapotranspiration-related uncertainty in climate change impacts on river flow: An assessment for the Mekong river basin. J. Hydrol. 2014, 510, 259-279. [CrossRef]

144. Ul Hasson, S.; Pascale, S.; Lucarini, V.; Böhner, J. Seasonal cycle of precipitation over major river basins in south and southeast Asia: A review of the CMIP5 climate models data for present climate and future climate projections. Atmos. Res. 2016, 180, 42-63. [CrossRef]

145. Hoang, L.P.; Lauri, H.; Kummu, M.; Koponen, J.; van Vliet, M.T.H.; Supit, I.; Leemans, R.; Kabat, P.; Ludwig, F. Mekong river flow and hydrological extremes under climate change. Hydrol. Earth Syst. Sci. 2016, 20, 3027-3041. [CrossRef]

146. Thilakarathne, M.; Sridhar, V. Characterization of future drought conditions in the lower Mekong river basin. Weather Clim. Extremes 2017, 17, 47-58. [CrossRef]

147. Lyon, S.W.; King, K.; Polpanich, O.-U.; Lacombe, G. Assessing hydrologic changes across the lower Mekong basin. J. Hydrol. Reg. Stud. 2017, 12, 303-314. [CrossRef]

(c) 2018 by the authors. Licensee MDPI, Basel, Switzerland. This article is an open access article distributed under the terms and conditions of the Creative Commons Attribution (CC BY) license (http://creativecommons.org/licenses/by/4.0/). 